\title{
PERAN DAN FUNGSI KECAMATAN DALAM PENYELENGGARAAN PEMERINTAHAN DAERAH DI KOTA SEMARANG DAN KABUPATEN SEMARANG PROVINSI JAWA TENGAH
}

\author{
Role and Function Sub Distric in The Implementation of Local Government In \\ Semarang City And District of Semarang Central Java Province
}

\author{
Gunawan \\ Pusat Penelitian Pemerintahan Umum dan Kependudukan \\ Badan Penelitian dan Pengembangan (BPP) Kementerian Dalam Negeri \\ Jl. Kramat Raya No. 132 - Senen, Jakarta \\ E-mail: wawangunawan678@gmail.com \\ Dikirim: 17 September 2014; direvisi: 27 September; disetujui 12 Desember 2014
}

\begin{abstract}
Abstrak
Kecamatan dalam menjalankan fungsi penyelenggaraan pemerinnahan umum dan fungsi penyelenggaraan tugas-tugas yang telah diserahkan oleh Kabupaten Kota sesuai dengan Undang-Undang Nomor 32 Tahun 2004 tentang Pemerintahan Daerah dan Peraturan Pemerintah Nomor 19 Tahun 2008 tentang Kecamatan mengalami hambatan dalam penerapannya berupa kewenangan, kelembagaan, sumber daya manusia dan manajemen kecamatan, penelitian menggunakan pendekatan kualitatif, purposive sampling daerah yang telah diserahkan dan belum diserahkan kewenangannya kepada kecamatan, hasil penelitian menunjukan bahwa kewenangan yang telah diserahkan baik dari walikota dan bupati tidak sepenuhnya diserahkan, kelembagaan atau organisasi kecamatan belum menyesuaikan Peraturan Pemerintah Nomor 19 Tahun 2008, kualitas dan kuantitas sumber daya manusia menjadi hambatan dalam penyelenggaraan tugas-tugas atributif dan delegatif.

Kata kunci: Kecamatan, pemerintahan umum, kewenangan, kelembagaan, sumber daya manusia
\end{abstract}

\begin{abstract}
Subdistrict in performing common functions pemerinnahan implementation and administration functions of the tasks that have been submitted by Kanupaten City in accordance with the Law No. 32 Year 2004 on Regional Government and Government Regulation No. 19 Year 2008 on the District experienced a bottleneck in its application in the form of authority, institutional, resource human resources and management districts, the study used a qualitative approach, purposive sampling areas that have been submitted and have not been handed over authority to the districts, the results showed that the authority has submitted both the mayor and the regent was not fully submitted, institution or organization not adjust districts Government Regulation No. 19 in 2008, the quality and quantity of human resources become a bottleneck in the implementation of tasks and discretionary attributive

Keywords: Districts, public administration, authority, institutional, human resource
\end{abstract}

\section{PENDAHULUAN}

Kecamatan dan camat dalam sejarah perjalanan Indonesia sejak kemerdekaan hingga saat ini memiliki eksistensi yang sangat penting dan unik dengan peranperan penting yang disandangnya. Pengingkaran terhadap kecamatan dan camat sebenarnya merupakan sesuatu yang tidak berdasar, a-historis, dan perlu segera diluruskan kembali oleh Pemerintah, bila hal ini dapat menimbulkan permasalahan-permasalahan yang mengganggu jalannya pemerintahan dan pelayanan publik di daerah-daerah. Penelitian ini merupakan evaluasi terhadap eksistensi kecamatan dan camat dalam Negara Kesatuan Republik Indonesia di masa Undang-Undang No. 32 Tahun 2004 yang berusaha mengungkap permasalahanpermasalahan yang dihadapi kecamatan dan camat, khususnya terkait dengan relasinya dengan pemerintahan di atas (kabupaten/kota, provinsi dan Pusat) dan di bawahnya (desa/kelurahan). Perlu dicatat, Peraturan Pemerintah No. 19 Tahun 2008 tentang Kecamatan (sebagai aturan pelaksana UU No. 32 Tahun 2004), telah mengatur secara cukup rinci mengenai kecamatan dan camat. Akan tetapi, pelaksanaan PP tersebut pada sejumlah daerah terhambat oleh sikap-sikap para bupati/walikota yang dengan berbagai alasan yang mereka buat, cenderung untuk melakukan sentralisasi kekuasaan dan enggan untuk berbagi kekuasaan/kewenangan (desentralisasi) kepada para camat.

Bila kita melihat kepustakaan tentang camat dan lembaga kecamatan dapat diketahui di Indonesia ataupun di nusantara sudah cukup lama, jauh sebelum masa kemerdekaan Indonesia. Istilah camat kiranya telah dikenal masyarakat khususnya di Jawa dan Madura, sejak sebelum penjajahan Belanda. Di Jawa Barat terdapat istilah cutak yang peranannya sama dengan camat, yaitu seseorang yang mengepalai dan membina suatu wilayah yang biasanya terdiri beberapa desa (Bayu Surianingrat, 1981: 1). Di dalam 
pasal 70 R.R (R.R = Regeringsreglement, singkatan dari Reglement op het beleid der Regering in Nederlands Indie- Reglemen tentang kebijaksanaan Pemerintah di Hindia Belanda, Stbl.1854 No. 2) yang menjadi peraturan pokok dari pemerintahan dalam negeri di Hindia Belanda, dan baru dikeluarkan pada tahun 1854 tercantum sebagai berikut: ${ }^{1}$

Pasal tersebut menunjukkan dan membuktikan adanya struktur Pemerintahan Indonesia yang asli sejak sebelum kedatangan Belanda. Pemerintahan di daerah yang disusun menutut R.R sebenarnya hanya memasukkan struktur pemerintahan di dalam hukum dan hanya meniru atau melanjutkan atau sesuai dengan susunan Pemerintahan asli Indonesia, bahkan sebutan-sebutan jabatan yang ada tetap dipergunakan. Misalnya: lurah, kuwu, camat, wedana, bupati. Demikian pula gelar-gelar yang ada tetap dipakai seperti aria, adipati, tumenggung, pangeran, dan sebagainya.

Sebagai suatu organisasi yang hidup dan melayani kehidupan masyarakat yang penuh dinamika, kecamatan menghadapi banyak masalah. Kompleksitas masalah yang dihadapi berkaitan erat dengan banyaknya jumlah penduduk yang dilayani, tingkat heterogenitasnya (asal-usul, pendidikan, umur, maupun kemampuan ekonomi), karakteristik wilayah maupun banyaknya desa/ kelurahan di lingkungan kerjanya. Salah satu implikasi negatif dari penafsiran berlebihan dimaksud adalah pengubahan status, fungsi dan kedudukan kecamatan dari organisasi kewilayahan menjadi Satuan Kerja Perangkat Daerah (SKPD). Berbicara tentang kedudukan kecamatan, di mana UU Nomor 5 Tahun 1974, kecamatan merupakan wilayah administrasi pemerintahan, sedangkan UU Nomor 22 Tahun 1999, kecamatan merupakan wilayah kerja camat sebagai perangkat daerah kabupaten dan daerah kota (pasal 1 huruf m).

Dengan demikian, kecamatan bukan lagi wilayah administrasi pemerintahan. camat bukan lagi Kepala Wilayah yang memiliki kewenangan sebagai penguasa wilayah. Menurut UU Nomor 22 tahun 1999, kecamatan hanyalah merupakan wilayah kerja camat sebagai perangkat daerah, artinya kedudukan camat di kecamatan tidak berbeda jauh dengan perangkat daerah lainnya yang ada di kecamatan seperti Kepala cabang dinas, Kepala UPTD. Sehingga camat tidak secara otomatis mempunyai kewenangan untuk

\footnotetext{
1 "Kabupaten-kabupaten di Jawa dan Madura, jika dipandang perlu oleh Gubernur Jenderal dibagi dalam distrik-distrik. Tiap distrik diperintah oleh seorang Kepala Pribumi dengan sebutan jabatan menurut adat-kebiasaan pribumi. Instruksi-instruksi untuk Kepala Distrik dan hubungannya dengan pejabat-pejabat Eropa ditentukan oleh Gubernur Jenderal. Di dalam Provinsi penentuan tersebut dalam kalimat di atas dilakukan oleh Gubernur (Stbl.1854 No.2)
}

menjalankan urusan pemerintahan umum yang meliputi pengawasan, koordinasi serta kewenangan lainnya. camat hanya menjalankan tugas pokok sebagai unsur lini yakni "to do, to act" artinya kegiatan camat beserta jajarannya bersifat operasional, memberikan pelayanan langsung kepada masyarakat. camat tidak lagi memiliki kewenangan atributif melainkan hanya memiliki kewenangan delegatif artinya camat menerima pelimpahan sebagian kewenangan pemerintahan dari bupati/walikota; tanpa adanya pelimpahan kewenangan dari bupati/walikota. camat tidak dapat menjalankan aktivitasnya secara sah, sebagai kewenangan yang delegatif diberikan oleh bupati/walikota.

Pada masa berlakunya UU Nomor 5 Tahun 1974, camat merupakan kepala wilayah. Pada pasal 76 dinyatakan: "setiap wilayah dipimpin oleh seorang kepala wilayah." Dalam pasal 77 dinyatakan bahwa kepala wilayah kecamatan disebut camat. Dalam pasal 80 dinyatakan "kepala wilayah sebagai wakil pemerintah adalah penguasa tunggal di bidang pemerintahan dalam wilayahnya dalam arti memimpin pemerintahan mengoordinasikan pembangunan dan membina kehidupan masyarakat di segala bidang."

Wewenang, tugas dan kewajiban camat selaku kepala wilayah kecamatan sama dengan wewenang, tugas, dan kewajiban kepala wilayah lainnya, yakni gubernur, bupati, dan walikota. Pasal 81 secara lengkap dijelaskan bahwa wewenang, tugas dan kewajiban kepala wilayah adalah membina ketentraman dan ketertiban di wilayahnya sesuai dengan kebijaksanaan yang ditetapkan oleh pemerintah; melaksanakan segala usaha dan kegiatan di bidang pembinaan ideologi, negara dan politik dalam negeri serta pembinaan kesatuan bangsa sesuai dengan kebijaksanaan yang ditetapkan oleh pemerintah; menyelenggarakan koordinasi atas kegiatan-kegiatan instansi-instansi vertikal dan antara instansi-instansi vertikal dengan dinas-dinas daerah, baik dalam perencanaan maupun dalam pelaksanaan untuk mencapai dayaguna dan hasil guna yang sebesar-besarnya; membimbing dan mengawasi penyelenggaraan pemerintahan daerah; mengusahakan secara terus-menerus agar segala peraturan perundangundangan dan peraturan daerah dijalankan oleh instansi-instansi pemerintah dan pemerintah daerah serta pejabat-pejabat yang ditugaskan untuk itu serta mengambil segala tindakan yang dianggap perlu untuk menjamin kelancaran penyelenggaraan pemerintah; melaksanakan segala tugas pemerintahan yang dengan atau berdasarkan peraturan perundang-undangan diberikan kepadanya; melaksanakan segala tugas pemerintah yang tidak termasuk dalam tugas sesuatu instansi lainnya.

Dari sini terlihat betapa kuatnya posisi dan kewenangan seorang camat di wilayah kecamatan. camat adalah kepala wilayah, wakil pemerintah pusat, dan penguasa tunggal di wilayah kecamatan yang dapat mengambil segala tindakan yang dianggap perlu untuk menjamin kelancaran penyelenggaraan 
pemerintah. Meskipun camat adalah bawahan bupati/walikota, camat mempunyai kewenangan yang cukup besar di wilayahnya. Tidak heran pada masa UU Nomor 5 Tahun 1974, camat dapat memutuskan segala sesuatu tanpa perlu mengkonsultasikannya dengan bupati.

Pada masa setelah berlakunya UU Nomor 22 Tahun 1999 dan kemudian UU Nomor 32 Tahun 2004, camat tidak lagi menjadi kepala wilayah, melainkan sebagai perangkat daerah. Pasal 120 ayat (2) UU Nomor 32 Tahun 2004 dinyatakan bahwa perangkat daerah kabupaten/kota terdiri atas sekretariat daerah, sekretariat DPRD, dinas daerah, lembaga teknis daerah, kecamatan, dan kelurahan. Jadi, sebenarnya dilihat secara hukum posisi camat disejajarkan dengan posisi para kepala dinas daerah dan lurah. Hal ini tentu sangat berbeda jauh ketika camat waktu itu masih mengacu pada UU Nomor 5 Tahun 1974.

Lebih lanjut pada Pasal 126 ayat (2) menyatakan bahwa camat yang dalam pelaksanaan tugasnya memperoleh pelimpahan sebagian wewenang bupati atau walikota untuk menangani sebagian urusan otonomi daerah. Jadi, berdasarkan ayat (2) ini seorang camat mendapat kewenangan yang dilimpahkan atau diberikan oleh bupati atau walikota, untuk menangani sebagian urusan otonomi daerah.

UU Nomor 32 Tahun 2004 dinilai tidak memberi cukup ruang bagi camat untuk menjalankan peran yang diharapkan publik. Peran camat ditentukan oleh bagaimana bupati atau walikota mendelegasikan kewenangan kepada camat. Masalahnya, di hampir semua daerah di Indonesia camat belum mendapatkan delegasi kewenangan dari bupati atau wali kota secara maksimal. Pemerintah daerah cenderung mengedepankan logika sektoral dan belum mampu memberdayakan kecamatan dalam logika kewilayahan.

Pasal 126 Ayat 3 UU No 32 Tahun 2004. Tugas umum yang dimaksud itu berbeda maknanya dengan urusan pemerintahan umum sebagaimana termaktub dalam UU No 5 Tahun 1974. Pada saat ini tugas umum pemerintahan yang diselenggarakan oleh camat, tidak dimaksudkan sebagai pengganti urusan pemerintahan umum melainkan hanya mencakup tiga jenis kewenangan, yaitu kewenangan melakukan koordinasi yang meliputi lima bidang kegiatan, kewenangan melakukan pembinaan dan kewenangan melaksanakan pelayanan kepada masyarakat. Hal ini yang mengakibatkan camat terasa "tidak mempunyai gigi” ketika berhadapan dengan kepala SKPD atau UPT, padahal masyarakat masih memposisikan camat berperan sebagai kepala wilayah.

Sejalan dengan itu, camat tidak lagi ditempatkan sebagai Kepala Wilayah dan Wakil Pemerintah Pusat seperti yang terdapat dalam Undang-Undang Nomor 5 Tahun 1974, melainkan sebagai perangkat daerah. Seperti yang dikatakan oleh Prof. Koeswara Kertapradja, camat tidak lagi berkedudukan sebagai kepala wilayah kecamatan dan sebagai alat pemerintah pusat dalam menjalankan tugas-tugas dekonsentrasi. Ia telah beralih menjadi perangkat daerah yang hanya memiliki sebagian kewenangan otonomi daerah dan penyelenggaraan tugas-tugas dekonsentrasi. camat telah beralih menjadi perangkat daerah yang hanya memiliki sebagian kewenangan otonomi daerah dan penyelenggaraan tuga-tugas umum pemerintahan dalam wilayah kecamatan. Sedangkan dalam Pasal 126 ayat (3) huruf a Undang-undang Nomor 32 Tahun 2004, camat memiliki kewenangan untuk membina penyelenggaraan pemerintahan desa. Yang dimaksud membina dalam ketentuan ini adalah dalam bentuk fasilitasi pembuatan peraturan desa dan terwujudnya adminstrasi tata pemerintahan yang baik.

Kalau diperhatikan dalam tata hubungan kerja kecamatan yang dimanifestasikan pada peran camat melakukan hubungan dengan berbagai instansi seperti: (a) Bupati/walikota melalui sekretaris daerah, sifatnya hirarkis karena camat adalah bawahan bupati/ walikota, (b) Hubungan dengan dinas daerah dan lembaga teknis daerah lainnya, bersifat koordinatif dan teknis fungsional, apabila di dalam organisasi kecamatan terdapat seksi-seksi yang menjalankan fungsi dinas teknis dalam rangka memberikan pelayanan kepada masyarakat, (c) Hubungan dengan Pemerintah Desa, bersifat koordinatif dan fasilitatif (tidak lagi bersifat hirarkhis) tetapi desa sebagai kesatuan masyarakat yang memiliki kewenangan mengatur dirinya sendiri (self governing community), secara organisatoris desa tidak memiliki hubungan hirarkhis dengan kabupaten/kota, akan tetapi dilihat dari kepentingannya terdapat hubungan yang bersifat hirarkhis dengan melihat pada prinsip umum yang dipakai artinya bahwa kepentingan masyarakat yang lebih kecil tunduk pada kepentingan masyarakat luas, (d) Hubungan dengan Pemerintahan Kelurahan, (Lurah) bersifat hirarkhis, sebab lurah adalah bawahan dari camat. Di dalam hubungan kewenangan camat dengan Lurah ada hal yang tidak lazim secara teoritis, bila diamati pada pasal 67 ayat (4) Undang-Undang Nomor 22 Tahun 1999, dinyatakan bahwa "Lurah menerima pelimpahan sebagian kewenangan pemerintahan dari camat", pada hal prinsip utama dalam pendelegasian kewenangan adalah kewenangan yang bersifat atributif, sedangkan kewenangan yang bersifat delegatif tidak dapat didelegasikan kepada pihak lain, karena mempersulit pembiayaan yang pertanggungjawabannya; dan (e) Hubungan dengan instansi vertikal yang ada di kecamatan tidak otomatis bersifat koordinatif, karena camat tidak lagi sebagai kepala wilayah, sehingga Peraturan Pemerintah Nomor 6 tahun 1988 tentang Koordinasi Instansi Vertikal di Daerah, tidak berlaku lagi bagi camat. Koordinasi dapat dilakukan oleh camat apabila ada delegasi kewenangan dari bupati/walikota, hanya sebatas untuk dinas daerah saja, sedangkan terhadap instansi vertikal yang ada di kecamatan (polsek, PLKB dan lainnya) sifatnya hubungan kerja biasa.

Atas dasar uraian di muka maka secara umum dapat dikatakan bahwa faktor-faktor penyebab 
permasalahan yang dihadapi camat antara lain: Undang-Undang (UU) No. 32 Tahun 2004 tentang Pemerintahan Daerah, terutama pada Pasal 126, yang mengamanatkan bupati dan walikota untuk menetapkan dan menuangkan tugas dan fungsi kecamatan ke dalam Peraturan bupati/walikota belum diikuti sebagaimana mestinya, PP No. 19 Tahun 2008 tentang Kecamatan belum menguraikan tugas dan fungsi kecamatan secara lebih rinci, sehingga sulit digunakan oleh bupati dan walikota sebagai norma yuridis untuk menetapkan Peraturan bupati/walikota tentang pelimpahan sebagian wewenang pemerintahan daerah kepada camat. Informasi dari Ditjen PUM Kemendagri (April 2014) didapatkan data, dari 486 kabupaten/kota di Indonesia hanya ada sekitar 193 kabupaten/kota yang telah melimpahkan sejumlah kewenangan pemerintahan daerah kepada camat. Jadi bila dipresentasekan hanya sekitar 39,71\% Kepala Daerah (bupati dan walikota) yang telah memberi wewenang kepada camat dalam melaksanakan sebagian penyelenggaraan pemerintahan daerah.

Peraturan Pemerintah No. 19 Tahun 2008 tentang Kecamatan diimplementasikan di daerahdaerah ditinjau dari faktor-faktor kewenangan, kelembagaan, SDM dan dukungan pendanaan?, Bagaimana pemetaan permasalahan yang dihadapi kecamatan dan camat di daerah-daerah?, Bagaimana solusi kebijakan atas permasalahan-permasalahan yang dihadapi kecamatan dan camat yang mendukung pelayanan publik dan efektivitas penyelenggaraan pemerintahan dan pembangunan dalam ikatan NKRI. Maksud Pusat Litbang Pemerintahan Umum dan Kependudukan Badan Penelitian dan Pengembangan Kementerian Dalam Negeri memandang perlu untuk melakukan kegiatan penelitian kebijakan guna menelaah aspek-aspek pengaturan tentang camat dan pelimpahan kewenangan Kepala Daerah (bupati dan walikota) kepada camat yang selama ini tidak secara maksimal dilaksanakan oleh Pemerintah Daerah.

Tujuan penelitian ini adalah untuk mengkaji reposisi peran dan tugas fungsi camat dalam penyelenggaraan pemerintahan dan pembangunan daerah dalam ikatan NKRI, memposisikan camat agar dapat melakukan fungsi pelayanan publik di garda depan dalam ikatan NKRI, memposisikan camat dalam melakukan tugas umum pemerintahan secara profesional sehingga camat secara otomatis mendapatkan pelimpahan kewenangan dari kepala daerah dalam ikatan NKRI.

Sasaran penelitian ini adalah agar diperoleh gambaran yang jelas tentang peran dan fungsi camat; Diperolehnya usulan agar camat direposisikan sebagai Kepala Wilayah. Ruang lingkup Penelitian ini meliputi Pelimpahan kewenangan dari Kepala Daerah (bupati/ walikota) kepada camat; Undang-Undang Nomor 32 Tahun 2004; Peraturan Pemerintah No 19 Tahun 2008.

Hasil Penelitian ini diharapkan dapat bermanfaat bagi Pemerintah dan Dewan Perwakilan Rakyat Republik Indonesia (DPR-RI) dan khususnya
Direktorat Jendral Pemerintahan Umum Kementerian Dalam Negeri.

Desentralisasi merupakan konsekuensi dari demokratisasi. Tujuannya adalah membangun good governance mulai dariakar rumput politik. Beberapa kasus semisal penolakan laporan pertanggungjawaban (LPJ) bupati yang oleh sementara kalangan dinilai sebagai dampak negatif dari hiper-demokratisasi, yang merupakan realisasi dari ide desentralisasi. LPJ hanya satu kasus. Pada akhirnya masyarakat lebih banyak disuguhi desentralisasi sebatas retorika politik, demokratisasi sebagai pembungkus perjuangan merebut kekuasaan, serta good governance sebagai mimpi indah penghias tidur di saat perut rakyat semakin lapar (Riswandha Imawan, dalam Syamsuddin Haris (Ed), 2005: 40).

Implikasi dari pandangan ini adalah masih dirasakan perlunya pengawasan, nasehat atau bahkan arahan dari Pemerintah. Peran ini dapat dimungkinkan apabila makna dari desentralisasi menyangkut pula dekonsentrasi (desentralisasi administratif). Memang dimensi politik dari konsep ini sangat lemah. Instansi pemerintah tidak mempunyai kewenangan politik untuk menetapkan kebijakan sendiri, karena tidak memiliki lembaga perwakilan rakyat di daerah. Tidak ada keterikatan politik antara instansi pemerintah dengan masyarakat yang dilayani. Urusan instansi pemerintah yang ada adalah menjadi field administrator yang menjamin terselenggaranya urusan atau program Pemerintah. Namun demikian, instansi dekonsentrasi ini dibutuhkan agar Pemerintah dapat melakukan pelayanan langsung kepada masyarakat, serta menjadi pengawas terhadap jalannya pemerintahan daerah otonom.

\section{METODE PENELITIAN}

Penelitian ini menggunakan pendekatan kualitatif pemilihan sampel daerah penelitian berdasarkan teknik purposive sampling (pengambilan sampel bertujuan). Ruang lingkup penelitian ini dibatasi atas kriteria Kecamatan baik yang telah mendapatkan pelimpahan kewenangan dari Kepala Daerah maupun yang belum dan didasarkan juga atas tipologi kecamatan yang telah ditentukan sebagai berikut: Kecamatan di kabupaten/kota pada ibukota negara; Kecamatan di kabupaten/kota pada provinsi penerima otonomi khusus; Kecamatan di kabupaten/ kota sebagai kawasan pariwisata; Kecamatan di kabupaten/ kota sebagai kawasan industri; Kecamatan di kabupaten/ kota sebagai kawasan pertanian dan perkebunan; dan Kecamatan di kabupaten/ kota sebagai kawasan pesisir dan pantai; Berdasarkan kriteria dan tipologi kecamatan yang telah disebutkan maka lokasi penelitian yang ditentukan secara purposif yaitu salah satu diantaranya adalah Provinsi Jawa Tengah yang menjadi locus penelitian ini.

Metode deskriptif dimaksudkan untuk mengumpulkan informasi dimaksud menggunakan pendekatan (jenis) survei yakni mengumpulkan data 
yang relatif terbatas (sampel survei) dari sejumlah kasus yang relatif besar jumlahnya, dengan cara wawancara (disiapkan suatu pedoman wawancara), (Sevilla 1993:76). Pendekatan yang digunakan dalam penelitian ini adalah pendekatan kualitatif dan kuantitatif.

\section{HASIL DAN PEMBAHASAN}

Provinsi Jawa Tengah, yang sesuai namanya terletak di bagian tengah Pulau Jawa, memiliki luas wilayah $32.548 \mathrm{~km}^{2}$, Jawa Tengah dikenal sebagai "jantung" budaya Jawa. Meskipun demikian di provinsi ini ada pula suku bangsa lain yang memiliki budaya yang berbeda dengan suku Jawa seperti suku sunda, Tionghoa-Indonesia, Arab-Indonesia dan IndiaIndonesia yang tersebar di seluruh provinsi ini.

Kependudukan di wilayah Provinsi Jawa Tengah tahun 2011 sebanyak 32.643.612 jiwa dengan tingkat kepadatan penduduk 1.003 jiwa per $\mathrm{km}^{2}$. Penyebaran penduduk di Provinsi Jawa Tengah masih bertumpu di Kabupaten Brebes yakni sebesar 5,35 persen dan Kabupaten Cilacap sebesar 5,1 persen sedangkan yang terendah Kota Magelang sebesar 0,4 persen. Sementara dilihat dari kepadatan penduduk kabupaten/kota yang paling tinggi tingkat kepadatan penduduknya adalah Kota Surakarta yakni sebanyak 11.393 jiwa per $\mathrm{km}^{2}$ dan yang paling rendah adalah Kabupaten Blora dengan tingkat kepadatan penduduk sebanyak 465 jiwa per $\mathrm{km}^{2}$. Dilihat dari sisi laju pertumbuhan selama sepuluh tahun terakhir (20002010) Provinsi Jawa Tengah sebesar 0,37 persen lebih rendah dari pertumbuhan nasional penduduk nasional $(1,49 \%)$. Sementara untuk laju pertumbuhan penduduk kabupaten/kota tertinggi terdapat di Kota Semarang1,41 persen sedangkan yang terendah di Kabupaten Wonogiri sebesar minus 0,43 persen.

Kewenangan Kecamatan yang bapak/ibu pimpin telah diserahkan kewenangan oleh bupati/walikota Lokus penelitian pada Kota Semarang diwakili oleh Kecamatan Pedurungan, Kecamatan Semarang Barat, Kecamatan Mijen, Kecamatan Gunungpati, Kecamatan Tembalang. sedangkan pada Kabupaten Semarang yang menjadi sample dalam penelitian ini adalah Kecamatan Ungaran Timur dan Kecamatan Bergas, sebagian besar sudah dilimpahkan kewenangannya, Sebagian besar khususnya di Kota Semarang sudah mengeluarkan pelimpahan kewenangan dengan Peraturan walikota Semarang Nomor 19 Tahun 2012 Tentang Perubahan atas Perwal 32 Tahun 2009 Tentang Pendelegasian sebagian Urusan Pemerintahan yang menjadi kewenangan walikota kepada camat kota Semarang.

Kabupaten Semarang juga sudah memberikan pelimpahan sebagian kewenangannya kepada camat dengan Peraturan bupati Semarang Nomor 117 Tahun 2012, dengan demikian jika bupati dan walikota sudah membuat peraturan tentang pelimpahan kewenangannya kepada camat maka pelaksanaannya diikuti dan dipatuhi oleh seluruh kecamatan yang berada pada wilayah bupati maupun walikota, namun untuk perijinan galian meratakan gunung yang digunakan menguruk laut untuk permukiman atau kepentingan umum walikota periode sekarang hanya pernah mengeluarkan izin sekali dalam pemerintahan-nya dan sampai sekarang belum pernah mengeluarkan izin penggalian lagi.

walikota tidak pernah lagi mengeluarkan izin galian namun pada prakteknya masih dijumpai adanya oknum-oknum baik itu dari unsur masyarakat maupun dari aparat pemerintah daerah yang menggunakan dan memanfaatkan sumber alam milik daerah digunakan untuk kepentingan pribadi dan golongan.

Bidang apa-apa saja kewenangan kepala daerah bupati/walikota yang telah didelegasikan kepada kecamatan Pendelegasian yang diserahkan dari bupati/walikota meliputi bidang-bidang yang menjadi urusan Pemerintahan Daerah, pemerintahan, pendidikan, kesehatan, pekerjaan umum, perumahan, perhubungan, lingkungan hidup, pertanahan, kependudukan dan pencatatan sipil, pemberdayaan perempuan dan perlindungan anak, KB dan keluarga sejahtera, sosial, koperasi dan usaha kecil menengah, kebudayaan dan pariwisata, pemuda dan olah raga, kesatuan bangsa dan politik dalam negeri, komunikasi dan informatika, pertanian dan ketahanan pangan, energi, kelautan dan perikanan, perdagangan, dan perindustrian.

Bidang-bidang yang didelegasikan kewenangannya dari kabupaten kota ke kecamatan merupakan bagian dari bidang-bidang yang menjadi urusan daerah yang diserahkan kecuali urusan pemerintahan yaitu fiskal nasional, pertahanan, keamanan, moneter, agama, politik luar negeri, yustisi, urusan-urusan inilah yang menjadi urusan pemerintah sedangkan urusan yang menjadi urusan pemerintah daerah adalah sebanyak 31 urusan seperti pendidikan; kesehatan; pekerjaan umum; perumahan; penataan ruang; perencanaan pembangunan; perhubungan; lingkungan hidup; pertanahan; kependudukan dan catatan sipil; pemberdayaan perempuan dan perlindungan anak; keluarga berencana dan keluarga sejahtera; sosial; ketenagakerjaan dan ketransmigrasian; koperasi dan usaha kecil dan menengah; penanaman modal; kebudayaan dan pariwisata; kepemudaan dan olah raga; kesatuan bangsa dan politik dalam negeri; otonomi daerah, pemerintahan umum, administrasi keuangan daerah, perangkat daerah, kepegawaian, dan persandian; pemberdayaan masyarakat dan desa; statistik; kearsipan; perpustakaan; komunikasi dan informatika; pertanian dan ketahanan pangan; kehutanan; energi dan sumber daya mineral; kelautan dan perikanan; perdagangan; dan perindustrian. Pemerintahan, Ekonomi dan Pembangunan, Pendidikan dan Kesehatan, Sosial dan Kesejahteraan Rakyat, Pertanahan, Kepegawaian, Pelayanan Umum.

Dengan demikian dari urusan-urusan tersebut yang di jabarkan dalam bidang-bidang kemudian di delegasikan ke kecamatan belum sepenuhnya diserahkan hanya sebatas formalitas saja namun dalam 
pelaksanaannya belum sepenuhnya terlebih lagi dengan perizinan, kecamatan hanya di batasi dengan perizinan $100 \mathrm{~m} 2$ sampai dengan $200 \mathrm{~m} 2$ saja yang diserahkan. Bidang-bidang yang diserahkan dari kabupaten kota yang dilimpahkan ke kecamatan hanya sebatas rekomendasi atau fasilitasi dan koordinasi.

Pelaksanaan kewenangan tersebut mengalami permasalahan/hambatan keseluruhan lokasi sampel menjawab ya atau ada namun alasan hambatanya berfariasi antara lain bahwa tidak semua kewenangan yang dilimpahkan disertai dengan anggaran, bahwa kewenangan yang dilimpahkan tidak maksimal hanya bersifat rekomendasi/pengantar, yang diserahkan pada umumnya hanya skala kecil seperti perijinan Ijin Mendirikan Bangunan (IMB) hanya pada kisaran 100 $\mathrm{m}^{2}$ sampai dengan $200 \mathrm{~m}^{2}$, bahwa kewenangan diberikan setengah setengah masih terdapat ego kepentingan SKPD, peran camat hanya sebatas perangkat daerah namun tidak bisa dipisahkan selaku kepala wilayah, Struktur organisasi sudah baik namun diisi personil yang kurang mumpuni, terbatasnya sumber daya manusia, pola pikir yang masih mengacu pola lama, Latar belakang disiplin ilmu yang tidak berasal dari pemerintahan, Pelimpahan kewenangan bupati belum disertai dengan kewenagan yang memadai, pejabat yang ada di kecamatan, belum mengikuti diklat, Masih ada anggapan, memilh bertugas di kabupaten daripada di kecamatan, camat sebagai kepala SKPD namun secara riil masyarakat umum masih menganggap bahwa kedudukan camat masih sebagai kepala wilayah sehingga dalam banyak hal yang masih mengerjakan/melaksanakan sesuatu yang sama seperti sebagai Kepala Wilayah, terbatasnya kualitas Sumber Daya Manusia, pelimpahan kewengan bupati belum secara signifikan disertai dengan SDM dan anggaran, masih dirasakan adanya persepsi yang memandang sebelah mata SKPD kecamatan dan kelurahan dibanding dengan SKPD lain seperti badan dan/atau dinas.

Sedangkan di Kabupaten Semarang terdapat Peraturan Bupati Semarang Nomor 18 Tahun 2007 Tentang Pelimpahan Sebagian Kewenangan Bupati Semarang Kepada Lurah di Kabupaten Semarang. Jawaban ini juga berkaitan dengan pertanyaan sebelumnya, bahwa pelimpahan yang diberika setengah-setengah bagaikan pala dilepas tapi ekor diikat begitu perumpamaan pelimpahan kewenangan saat ini.

Faktor-faktor yang mendukung dan memperlancar kecamatan dalam mengimplementasikan kewenangannya sangat bervariatif antara lain adanya koordinasi baik dengan SKPD terkait maupun warga masyarakat, kewenangan hanya bersifat rekomendasi sehingga tidak menimbulkan dampak yang berarti,a partisifasi masyarakat dan tokoh masyarakat yang baik dan mudah diajak bekerjasama, adanya internet, adanya koordinasi yang intensif antgara camat dengan bawahannya, kelurahan, MUSPIKA, UPTD/B dan instansi terkait dan menjalin kerjasama/silaturahmi dengan para pengusaha dan tokoh masyarakat di wilayahnya, masyarakatnya sekitar $86 \%$ sampai dengan $90 \%$ berada pada wilayah kecamatan sehingga memudahkan dalam bekerja, aparatur kecamatan sebagian besar memahami dan menguasai teknologi informasi, adanya budaya kerja yang positif, memiliki kode etik, adanya SPM dan SOP, diminati oleh investor tertentu, seperti investor pengembangan wisata agro, wisata alam, Hubungan personal yang sangat erat dengan para pimpinan dinas, instansi, lembaga lain di tingkat kecamatan seperti kapolsek, danramil, kepala KUA, sarana dan prasarana, kelancaran pelaksanaan kecamatan dalam melaksanakan pelimpahan kewenangan karena didukung oleh semua pihak yang terkait dengan kagiatan dan program yang dibuat kecamatan maupun SKPD/UPTD dan masyarakat di wilayah kecamatan.

Rekomendasi atau langkah-langkah yang diperlukan untuk lebih memberdayakan kecamatan terkait dengan kewenangan yang dimiliki Kecamatan seharusnya mempunyai kewenangan untuk memproses dan menerbitkan perijinan sehingga pelayanan masyarakat lebih optimal dan cepat, Bahwa untuk mendukung kegiatan sesuai dengan kewenangan yang diberikan kepada camat harus diikuti dengan anggaran guna memaksimalkan kegiatan tersebut, aktif mengusulkan kepada walikota/bupati agar dalam memberikan/menyerahkan sebagian kewenanagan dan urusan juga menyerahkan anggaran ke kecamatan, Melaksanakan pembangunan wilayah dengan melibatkan peran serta aktif dari masyarakat, Melaksanakan pembinaan kepada aparatur di lingkungan kecamatan, kelurahan dan masyarakat pada setiap kesempatan, Melaksanakan koordinasi intensif antara camat dengan bawahannya, kelurahan, MUSPIKA, UPTD dan instansi terkait serta menjalin kerjasama/silaturahmi dengan para pengusaha dan tokoh masyarakat di wilayahnya, melaksanakan inovasi/terobosan dalam melaksanakan pekerjaan, pengisian jabatan camat sesuai dengan disiplin dan latar belakang pemerintahan, Adanya diklat pemerintahan kecamatan, adanya kewenganan sebagai kepala wilayah, tesedianya kualitas SDM yang mewadai, pelimpahan kewengan diikuti dengan SDM dan Anggaran secara signifikan, rekomendasirekomendasi yang dibutuhkan dalam memerankan kecamatan yang diberi tugas dalam melaksanakan kewenangan tersebut yang paling mendasar adalah diserahkannya kewenangan kepada kecamatan namun didukung dengan anggaran yang cukup.

Kelembagaan atau organisasi Kecamatan sudah terbentuk dan berfungsi seperti yang diinginkan untuk lokasi sampel Kabupaten Semarang pada organisasi kecamatan terdiri dari 1 (satu) sekretaris 5 (lima) seksi, sedangkan untuk kecamatan yang terdapat pada lingkup walikota Semarang terdapat Peraturan Daerah Kota Semarang Nomor 14 Tahun 2008 Tentang Organisasi dan Tata Kerja Kecamatan dan Kelurahan di Kota Semarang dengan komposisi 1 (Satu) sekretaris, 5 (lima) seksi, dan sekretariat 3 (tiga) sub bagian, 
Kelembagaan atau organisasi Kecamatan sudah terbentuk berdasarkan Peraturan Daerah Nomor 20 Tahun 2008 tanggaal 23 Juli 2008 tentang Organisasi dan Tata Kerja Kecamatan dan Kelurahan di Kabupaten Semarang sebagaimana telah dirubah dengan Peraturan Daerah No.4 Tahun 2011, tanggal 19 Mei 2011 tentang Perubahan atas Peraturan Daerah Nomor 20 Tahun 2008 tanggaal 23 Juli 2008 tentang Organisasi dan Tata Kerja Kecamatan dan Kelurahan di Kabupaten Semarang. Berkaitan fungsi belum secara optimal berfungsi seperti yang diinginkan, karena terbatasnya kualitas SDM yang tersedia, dalam struktur organisasi, khususnya dibawah Sekretaris camat, tidak ada Sub bagian, minimal 2 (dua), khususnya perencanaan dan keuangan, umum dan kepegawaian, tugas dan fungsinya langsung dilaksanakan oleh staf/pelaksan, dari kedua model struktur kelembagaan masing-masing mempunyai alasan khususnya yang terdapat di Kabupaten Semarang mendudukan pada peran dan fungsi masing-masing yaitu dengan tema sedikit atau miskin struktur namun kaya fungsi tapi dalam pelaksanaannya dalam menjalankan peran dalam fungsi atibutuf dan delegatif mengalami kesulitan khsusnya pada sekretariat tidak memiliki subbag yang bertugas membantu sekretaris dalam membuat program dan menyusun perencanaan anggaran, mengevaluasi kinerja kecamatan, serta yang bertugas menghimpun data pendataan, struktur yang diinginkan dalam pelaksanaan kegiatan kecamatan dirinci habis dari mulai unsur lini maupun unsur pelaksana, sehingga sekretaris camat memiliki unsur staf setingkat eselon 4 (kasubbag) kepala sub bagianl. Sesuai dengan Peraturan Pemerintah 19 Tahun 2008 tentang kecamatan.

Gambaran struktur organisasi kecamatan ideal/yang diharapkan seperti kelembagaan organisasi yang terdapat di Peraturan Pemerintah Nomor 19 Tahun 2008 tentang kecamatan sudah ideal namun masih sebagian kabupaten kota masih menggunakan Peraturan Pemerintah Nomor 41 Tahun 2007 tentang Organisasi Perangkat Daerah, Struktur Organisasi yang ideal sebenarnya, apa yang sudah ada sekarang, ditambah ada 2 (dua) subbag di bawah Sekretaris camat, namun kuncinya harus diisi oleh personil yang sesuai dengan disiplin ilmu/atau ada diklat tertentu, Struktur Organisasi yang ideal sebenarnya, apa yang sudah ada sekarang, ditambah ada 2 (dua) subbag di bawah Sekretaris camat, Miskin struktur kaya fungsi seperti di Kabupaten Semarang ternyata dalam pelaksanaan tugas-tugas atributif dan tugas-tugas delegatif mengalami kendala dan hambatan, maksud dan tujuan melakukan miskin struktur dan kaya fungsi untuk penghematan dan efesiensi anggaran dalam membelanjakan rutin pegawai namun apa yang terjadi tidak sesuai yang diharapkan.

Organisasi Kecamatan selama ini (2 tahun terakhir) kegiatan yang dilakukan Kecamatan dalam dua tahun terkahir ini masih dalam lingkup pelayanan kepada masyarakat baik tugas-tugas atributif dan tugas-tugas yang dilegasikan bupati dan walikota, selain kedua tugas tersebut kecamatan masih bertanggungjawab terhadap semua yang terjadi di wilayahnya termasuk dalam kehidupan bermasyarakat, melaksanakan Tugas dan Fungsi sesuai dengan Peraturan bupati Semarang Nomor 92 Tahun 2011 tentang Tugas,Pokok dan Fungsi dan Rincian Tugas Kecamatan dan Kelurahan di Kabupaten Semarang dan Peraturan bupati Semarang Nomor 117 Tahun 2012 tentang Pelimpahan Sebagian Kewenangan bupati Semarang kepada camat di Kabupaten Semarang.

Perencanaan Kecamatan dan perangkat Kecamatan pada jangka pendek, menengah dan jangka panjang? Vivi misi (RPJMD) Visi misi kecamatan tahun 2010 - 2015 adalah "pelayanan prima, lingkungan nyaman dan masyarakat partisipasi pada tahun 2015" antara lain meningkatkan kwalitas pelayanan, meingkatkan kebersihan lingkungan, memberdayakan masyarakat dalam pembangunan, Rencana Jangka Pendek: Memfasilitasi dan mengkoordinasikan perwujudan prioritas Pembangunan Daerah Tahun 2015 di Kecamatan Ungaran Timur yang meliputi: Perwujudan Masyarakat Sehat, Perwujudan masyarakat berpendidikan dan berdaya saing, Perwujudan kedualatan pangan, Perwujudan kemandirian ekonomi yang berdaya saing, Perwujudan pemerintahan yang partisipatif, efektif efesien dan akuntabel, Perwjudan iklim usaha yang kondusif, Perwujudan budaya tertib, Perwujudan infrastruktur yang berkualitas dan merata, Perwujudan partisipasi masyarakat dalam pembangunan, Perwujudan kemandirian kelembagaan desa dan masyarakat, Perwujudan pengelolaan lingkungan hidup yang berkelanjutan, Rencana Jangka Menengah: Ikut menyiapkan bahan pembuatan RPJMD Kabupaten Semarang periode Tahun 2016 2020 dan mebuat Rencana Strategis Kecamatan Ungaran Timur tahun 2016 - 2020.

Pemerintah, Pemerintah Provinsi, Pemerintah kabupaten/kota kepada Kecamatan dan perangkat Kecamatan untuk dapat melakukan tugas dan fungsinya secara lancar dan profesional bagi pemerintah yaitu menaikan gaji PNS agar kehidupan PNS lebih layak dan lebih fokus terhadap pekerjaaanya, merubah aturan kepegawian menjadi UU ASN yang diharapkan meningkatkan performa PNS, Membuat PP nomor 53 Tahun 2010 Tentang Peraturan Disiplin PNS yang diharapkan bisa memperbaiki kedisiplinan PNS menjadi lebih baik, Provinsi, Pemerintah kota dan kabupaten yaitu menaikan nominal tunjangan penghasilan agar PNS lebih layak dan lebih fokus dalam pekerjaannya, melaksanakan inspeksi mendadak sewaktu-waktu ke semua SKPD, termasuk kecamatan dan kelurahan secara acak agar PNS takut melanggar aturan, melaksnakan razia/inspeksi mendadak terhadap PNS yang menyalahi aturan jam kerja dipusat-pusat keramaian, melaksanakan pembinaan buku-buku administrasi, keuangan, keamanan dan ketertiban, dll, 
memberikan berbagai fasilitas kepada kecamatan seperti merubah loket pelayanan masyarakat menjadi lebih representatif, memasang alat pengukur kepuasan masyarakat, memasang kamera cctv sebanyak 8 titik disemua kecamatan, selalu melibatkan aparat kecamatan dan kelurahan dalam setiap pembahasan masalah/rapat tertentu yang relevan, melaksanakan jalan sehat bersama walikota dan bupati di semua kelurahan secara bergiliran, perlu adanya evaluasi terkait dengan, meliputi Kedudukan Organisasi Kecamatan, Kedudukan camat dan Kewenangan camat serta Tugas dan Fungsi Pemerintah Kecamatan,

Bentuk hubungan koordinasi yang telah dilakukan oleh Kecamatan di lingkungan kerjanya koordinasi secara intensif dengan aparat keamanan baik secara formal maupun informal untuk menyusun strategi dan mengevaluasi situasi keamanan wilayah, koordinasi dengan instansi terkait untuk menuntaskan persoalan trantibum, misalnya pengajuan pemasangan traffic light, pemasangan rambu lalu lintas, penambahan jalan berlubang, koordinasi secara intensif dengan para lurah untuk mengoptimalkan tugas-tugas pemerintahan umum, patroli bersama aparat keamanan (polisi, TNI,Satpol PP) dalam operasi spanduk yang melanggar aturan dan spanduk tanpa ijin, penindakan terhadap pelanggar perda, operasi penindakan galian c, operasi penertiban atribut pemilu, rapat koordinasi bersama MUSPIKA, kepala Puskesmas, Kepala UPTD/B Kepla SMP dan SMA, Kepala KUA, PPL Pertanian dilakukan sebualn sekali, koordinasi aparat kecamatan dengan kelurahan per seksi Pemerintah, Pembangunan, Kesejahteraan Sosial, Ketentetraman dan Ketertiban Umum, Kependudukan, Kesekretariatan dilakukan paling sedikit satu (1) bulan sekali. hubungan koordinasi yang telah dilakukan oleh camat di llingkungan kerjanya, secara garis komando dengan secretariat dan masing-masing seksi, serta melakukan koordinasi dengan satuan kerja perangkat daerah dan/atau instansi vertical yang tugas dan fungsinya di bidang pemerintahan, pembangunan, trantibum, kesra dan pelayanan umum, hubungan koordinasi yang telah dilakukan oleh camat di llingkungan kerjanya, secara garis komando dengan secretariat dan masing-masing seksi, serta melakukan koordinasi dengan satuan kerja perangkat daerah dan/atau instansi vertical yang tugas dan fungsinya di bidang pemerintahan, pembangunan,trantibum,kesra dan pelayanan umum.

Tumpang tindih kewenangan antar Kecamatan dengan SKPD di lingkungan kerjanya Tidak ada tumpang tindih misalnya kegiatan pemberantasan nyamuk, puskesmas juga memiliki kegiatan yang sama, contoh meingkatkan ekonomi masyarakat, salah satunya dari sektor wisata, namun sektor wisata adalah domain/ranah dinas kebudayaan dan pariwisata. selama ini sudah ada aturan yang jelas tentang tugas pokok dan fungsi masing-masing SKPD terkait, tidak ada tumpang tindih, Kecamatan hanya sebatas memfasilitasi pemerintah desa/kelurahan, dan kordinasi atas kegiatan SKPD di wilayah Kecamatan, secara normative tidak ada tumpang tindih kewenangan. Kecamatan hanya sebatas memfasilitasi pemerintah desa/kelurahan, dan kordinasi atas kegiatan SKPD di wilayah Kecamatan. Namun secara riil kadang masih terdapat kegiatan yang mengesankan bahwa Kecamatan kepanjangan dari pada para SKPD tingkat Kabupaten, tumpang tindih kewenangan antar kecamatan dan SKPD pada lokasi sampel tidak terjadi karena dalam tugas sudah terdapat koordinasi yang baik dengan instansi vertikal dan instansi yang terkait dengan tugas dan fungsi kecamatan. Namun dalam kenyataannya terkadang kecamatan menjadi salah satu kepanjangan tangan dari SKPD.

Kewenangan-kewenangan khusus apa saja yang sebaiknya yang dapat diberikan oleh Pemerintah dibawah Kemendagri dengan pertimbangan harapannya agar kecamatan diberi anggaran yang cukup sehingga kecamatan dapat memberikan pelayanan yang maksimal kepada masyarakat. dibawah Pemerintaan Gubernur/kabupaten/kota karena sama-sama merupakan perangkat daerah sehingga koordinasi akan lebih mudah. Kewenangan lebih terkait perizinan skala kecil seperti izin usaha dan IMB sehingga tidak perlu sampai ke badan pelayanan dan perizinan terpadu, sudah cukup dibawah pembinaan Kepala Daerah, tinggal lebih dioptimalkan dan diperjelas, serta didukung dari segala hal, sudah cukup dibawah pembinaan Kepala Daerah, tinggal lebih dioptimalkan dan diperjelas, serta didukung dari segala hal, sudah cukup dibawah pembinaan Kepala Daerah, tinggal lebih dioptimalkan dan diperjelas, serta didukung dari segala hal, sebagian besar kecamatan memilih SOTK organisasi kecamatan dibawah pemerintah daerah secara kewilayahan dapat segera di komunikasikan dan dikoordinasikan peristiwa-peristiwa yang terjadi pada tingkat kecamatan.

Kecamatan yang diperlukan oleh masyarakat dan oleh pemerintah atasannya kewenangan yang penuh dalam rangka proses perizinan, harapan masyarakat terhadap kecamatan adalah kecamatan bisa meningkatkan kemajuan wilayah meliputi insfrastruktur wilayah, taraf hidup dan perekonomian masyarakat, untuk pembangunan sarana prasarana yang kini aturannya dikerjakan oleh rekanan/pihak ke 3 , masyarakat mengharapkan kecamatan merubah aturan tersebut menjadi pembangunan sarana dan prasarana bisa diserahkan kepada masyarakat lagi bukan ke rekanan/pihak ke 3 sehinggga bisa lebih optimal tanpa ada potongan unuk admisitrasi, menggaji rekanan dan pekerjaannya, pajak, dan lainlain sehingga pembangunan sarana prasaranalebih banyak dan optimal, Pemerintah di atas kecamatan berharap kecamatan bisa melaksanakan pelayanan terhadap masyaraat dengan sebaik-baiknya, mampu berkoordinasi dan membantu pelaksanaan tupoksi SKPD mereka, Harapan masyarakat tersebut bertentengan dengan Permendagri Nomor 32 Tahun 2011 tentang pedoman pemberian hibah dan bantuan sosial yang bersumber dari APBD, Harapannya agar 
kecamatan diberi anggaran yang cukup sehingga kecamatan dapat memberikan pelayanan yang maksimal kepada masyarakat, Dalam UU Nomor 32 Tahun 2004, dinilai tidak memberikan cukup ruang bagi camat untuk menjalankan peran yang diharapkan oleh public, camat tidak diberikan kewenangan atributif untuk melakukan pembinaan dan pengawasan terhadap desa,

Peran Pembina di tingkat Provinsi terkait dengan tugas dan fungsi Kecamatan di lokus penelitian (apakah ada masalah yang dijumpai) Pemerintah Provinsi memberikan pembinaan bagi aparatur Kecamatan melalui Pemerintah Kota dan Kabuapten. (tidak ada masalah), Adanya koordinasi antar kecamatan oleh pemerintah Provinsi, Pembinaan Gubernur dan SKPD di tingkat Provinsi kurang terasa karena Kecamatan tidak berada langsung di bawah mereka, Tidak ada, Tingkat Propinsi hanya banyak berkutat pada koordinasi kegiatan Propinsi yang ada di wilayah Kecamatan, Tidak ada, Tingkat Propinsi hanya banyak berkutat pada koordinasi kegiatan Propinsi yang ada di wilayah Kecamatan.

Saran terkait aparatur Kecamatan sehingga bermanfaat bagi kepentingan masyarakat daerahnya pembagian tugas antar seksi di kecamatan harus merata, aparat kecamatan harus bekerja dengan giat bagi yang belum bekerja dengan giat, ada yang rajin tapi ada yang malas, tegakan aturan kedisiplinan, ganti sistem presensi kehadiran dengan sidik jari sehingga jelas mana pegawai yang rajin dan pegawai yang tidak pernah berangkat kantor, tingkatkan kualitas SDM kecamatan dan kelurahan sehingga cakap dalam melaksankaan pekerjaan terutama yang berkaitan dengan komputer, tambah personil kecamatan dan kelurahan, perbaiki kesejahteraan PNS kecamatan dan kelurahan sehingga PNS di SKPD lain rela dan suka jika dipindahkan tempat bekerjanya ke kecamatan dan kelurahan dan tidak membangkang, perjelas tupoksi semua SKPD sehingga kecamatan dan kelurahan tidak terus menerus dimintai bantuan mengerjakan tugas dari berbagai macam SKPD, adanya peningkatan SDM dalam rangka pelayanan kepada masyarakat, adanya tambahan personil, SDM yang mampu dan berkualitas, aparatur di kecamatan dan kelurahan dilengkapi sesuai seksi sehingga tidak terjadi kekosongan karena mengganggu jalannya kegiatan, dibekali pelatihan-pelatihan yang terkait dengan pelayanan kepada masyarakat, kedudukan camat perlu dikembalikan kembali sebagai kepala wilayah yang disamping melaksanakan fungsi atributif, juga melaksanakan fungsi delegatif, diperlukan sosok camat yang mampu meningkatkan perannya terkait system dan struktur organisasi,pemberdayaan sumber daya manusia kecamatan dan mengoptimalkan fungsi pelayanan kepada masyarakat, Peran dan fungsi camat perlu diarahkan kepada fungsi atributif tanpa mengsampingkan fungsi kewenangan dari kepala daerah, kedudukan camat perlu dikembalikan kembali sebagai kepala wilayah yang disamping melaksanakan fungsi atributif, juga melaksanakan fungsi delegatif, diperlukan sosok camat yang mampu meningkatkan perannya terkait system dan struktur organisasi,pemberdayaan sumber daya manusia kecamatan dan mengoptimalkan fungsi pelayanan kepada masyarakat, peran dan fungsi camat perlu diarahkan kepada fungsi atributif tanpa mengsampingkan fungsi kewenangan dari kepala daerah.

Jumlah personil Kecamatan yang ideal menurut tugas dan fungsinya disesuaikan dengan struktur organisasi di PP 19 Tahun 2008 tentang Kecamatan atau PP 41 Tahun 2007 Tentang Organisasi Perangkat Daerah ditambah staf masing-masing bidang atau seksi atau bagian minimal 2 (dua) orang, satu Kecamatan 30 sampai dengan 50 orang/pegawai, jumlah personil Kecamatan yang ideal, disesuaikan dengan struktur organisasi yang ada, minimal masingmasing seksi ada 3 (tiga) pelaksana, jumlah personil Kecamatan yang ideal, disesuaikan dengan struktur organisasi yang ada, minimal masing-masing seksi ada 2 (tiga) pelaksana dan disekretariat ada 4 pelaksana.

Kompetensi/kapasitas Kecamatan serta jajarannya perlu dukungan tenaga ahli berkaitan dengan pertanahan dan pengadaan barang dan sarana prasarana karena beresiko hukum, tidak perlu cukup meningkatkan kualitas dan kuantitas SDM, pada saat ini kompetensi belum maksimal sehingga masih perlu adanya dukungan dari tokoh masyarakat, tenaga ahli dari pakar, kalangan profesional dan lainnya, kompetensi/Kapasitas kecamatan pada saat ini masih kurang, dikarenakan latar belakang yang tidak berasal dari pemerintahan, idealnya harus berasal dari pemerintahan, perlu dukungan dari segenap komponen terutama pengambil kebijakan bupati/walikota, kompetensi/Kapasitas kecamatan pada saat ini masih kurang, dikarenakan kualitas SDM yang tersedia masih kurang serta mental dan disiplin yang rendah, perlu dukungan dari segenap komponen terutama pengambil kebijakan bupati/walikota dalam menempatkan penyediaan SDM yang berkualitas.

Komposisi Muspika di tingkat Kecamatan dan di bawah kendali Kecamatan sudah berfungsi seperti seharusnya dudah tidak perlu ditambah, komposisi Muspika sudah berfungsi dan tidak perlu ditambah, komposisi Muspika sudah berjalan sebagaimana mestinya, Kendali Muspika belum belum sepenuhnya dibawah Kecamatan. Karena Muspika masih terikat dengan instansi induknya kebijakan dilakukan secara bersama-sama, komposisi Muspika di tingkat Kecamatan perlu ditambah Dinas/Instansi terkait di tingkat Kecamatan, karena tidak hanya mencakup polsek/koramil tapi juga dinas instansi teknis (Pertanian,Pendidikan,KBPP ,Puskesmas, Peternakan dll), komposisi Muspika di tingkat Kecamatan dibawah koordinasi dan perlu ditambah Dinas/Instansi terkait di tingkat Kecamatan, karena tidak hanya mencakup polsek/koramil tapi juga dinas instansi teknis 
(Pertanian,Pendidikan,KBPP,Puskesmas,Peternakan dll).

Alokasi anggaran bagi Kecamatan yang diperlukan sesuai dengan besaran kewenangan yang dimiliki untuk jalannya organisasi Kecamatan dibagi dalam 2 (dua) kelompok untuk: belanja langsung (kegiatan rutin dan pembangunan) berkisar antara Rp.9.000.000.000,- sampai dengan 12.000.000.000. dan belanja tidak langsung (gaji dan tunjangan) $\mathrm{Rp}$. 7.000.000.000,- sampai dengan Rp. 10.000.000.000,-, disesuaikan dengan kemampuan daerah.

Program/kegiatan dalam satu tahun anggaran di Kecamatan yang akan dilaksanakan terdiri dari 9 Program yang dirinci dalam 36 sampai dengan 40 Kegiatan, 6 (enam) program dan 19 (Sembilan belas) kegiatan, 6 (enam) program dan 18 (delapan belas) kegiatan.

Sumber dana dari mana saja supaya dapat berguna bagi kegiatan organisasi Kecamatan terdiri dari sumber dana APBD II, APBD dan APBN, Menggali potensi wilayah/swadaya dari masyarakat/pengusaha (sumbangan), APBD kota saja, baik yang masuk di anggaran kecamatan maupun masuk di anggaran SKPD lain di kota, Pemerintah Provinsi dan Pemerintah Pusat terkadang menmberikan bantuan namun melewati SKPD Kota tidak langsung ke kecamatan/kelurahan, Penambahan anggaran, Kecamatan tidak punya kewenangan untuk megelola pendapatan, Dari APBD kabupaten/kota, APBD Propinsi.

Solusi kegiatan terkait dengan anggaran Kecamatan dan perangkatnya camat dan perangkatnya berusaha sebisa mungkin mencari dana untuk melaksanakan pekerjaan tersebut, salah satunya adalah menggali potensi wilayah/swadaya dari masyarakat/pengusaha (sumbangan), dapat bekerjasama dengan pihak ke tiga CSR, Besaran anggaran Kecamatan, disesuaikan dengan kondisi wilayah, dan indicator, lain yang membedakan dengan Kecamatan lain, besaran anggaran Kecamatan, disesuaikan dengan beberapat indicator seperti kondisi wilayah, jumlah penduduk, orbitasi dll, solusi mengatasi permasalahan yang berkaitan dengan penganggaran pihak kecamatan mendapatkannya dari berbagai sumber dari penganggaran dari APBD maupun dari APBN bahkan ada beberapa kecamatan yang mendapatkan langsung dari bantuan pihak ketiga atau rekanan dan masyarakat.

Bentuk dukungan Kepala Daerah kepada Kecamatan dan perangkatnya memberikan penghargaan kepada yang berprestasi dan memberikan sanksi yang melanggar, kepala daerah mendukung sepenuhnya camat dan perangkatnya, bentuk dukungan bisa berupa kehadiran pada saat ada acara, dana ataupun sarana prasarana yang diusulkan kecamatan dan kelurahan/masyarakat, misalnya permohonan bantuan dari masyarakat kepada walikota pada saat dialog setelah jalan sehat di kelurahan, usulan pada saat musrenbang, diadakan bintek sosialisasi dan pelatihan yang bertujuan untuk menambah pengetahuan dan keterampilan perangkat. Khususnya sertifikasi pengadaan barang, bentuk dukungan Kepala Daerah kepada Kecamatan kususnya di bidang sarana dan prasarana serta kewengan yang dilimpahkan sudah baik, bahkan sudah diwacankan akan ada penambahan materi pelimpahan kewenangan yaitu infrastruktur dengan nilai dibawah Rp 200.000.000,-, bentuk dukungan Kepala Daerah kepada Kecamatan dan perangkatnya diwujudkan dengan memberikan apresiasi berupa reword dan funismen kepada karyawan yang berprestasi dan malas, selain itu juga dengan adanya dukungan kepala daerah dalam kegiatan yang diadakan kecamatan juga merupakan dukungan dan penghargaan yang setinggi-tingginya yang akan memebrikan dampak yang lebih luas terhadap motivasi baik dari camat dan perangkatnya dalam melaksanakan tugas atributif maupun legislatif.

Dukungan masyarakat diperlukan untuk lebih memberdayakan Kecamatan dan perangkatnya bentuknya antara lain partisifasi dan kehadiran masyarakat dalam suatu acara/kegiatan pemerintah kecamatan/kelurahan, bahkan bantuan swadaya/sumbangan dari masyarakat dengan berbagai macam bentuk (tenaga/uang/makanan), dalam bidang pembangunan perlu adanya pemberdayaan masyarakat, partisifasi dan dukungan masyarakat dalam kegiatan musyawarah perencanaan pembangunan, peningkatan swadaya masyarakat dan pembangunan sarpras wilayah. Partisifasi dan dukungan masyarakat dalam kegiatan musyawarah perencanaan pembangunan, peningkatan swadaya masyarakat dan pembangunan sarpras wilayah, dukungan masyarakat mutlak diperlukan, terkait aplikasi kebijakan-kebijakan pemerintah daerah, baik berupa saran/masukan dan pendanaan swadaya, dukungan masyarakat mutlak diperlukan, terkait aplikasi kebijakan-kebijakan pemerintah daerah, baik berupa saran/masukan dan pendanaan swadaya dll, bentuk dukungan yang dilakukan masyarakat terhadap kecamatan adalah dalam bentuk menghadiri setiap kegiatan dan program-program yang dilaksanakan oleh kecamatan, kecamatan yang menurut versi Undang-Undang 32 Tahun 2004 tentang Pemerintahan Daerah adalah sebagai SKPD namun pada kenyataanya masyarakat masih merasakan kondisi dan situasi seperti Undang-Undang Nomor 5 Tahun 1974 tentang Pemerintahan Daerah bahwa kecamatan adalah sebagai kepala wilayah maka setiap ada persoalan kemasyarakatan yang berada di wilayah atau tingkat kecamatan masyarakat hanya tahu bahwa mereka berada pada wilayah kecamatan.

Tugas-tugas delegatif (PP 19 Tahun 2008) seperti perizinan, rekomendasi, koordinasi, pembinaan, pengawasan, fasilitasi, penetapan, penyelenggaraan pemerintahan telah dilaksanakan dengan prinsip. 
Tabel 1. Koordinasi, Integrasi, Sinkronisasi dan Simplikasi

\begin{tabular}{|c|c|c|c|c|c|}
\hline KISS & $\begin{array}{c}\text { Sangat } \\
\text { Baik }\end{array}$ & Baik & $\begin{array}{c}\text { Cukup } \\
\text { Baik }\end{array}$ & $\begin{array}{c}\text { Kurang } \\
\text { Baik }\end{array}$ & $\begin{array}{c}\text { Sangat } \\
\text { Kurang } \\
\text { Baik }\end{array}$ \\
\hline Melaksanakan koordinasi dengan lintas sektor terkait & $2 \mathrm{kab} / \mathrm{kot}$ & $2 \mathrm{kab} / \mathrm{kot}$ & & & \\
\hline Telah dilakukan dengan terIntegrasi & $2 \mathrm{kab} / \mathrm{kot}$ & $1 \mathrm{kab} / \mathrm{kot}$ & $1 \mathrm{kab} / \mathrm{kot}$ & & \\
\hline Tugas-tugas sudah dilakukan dengan sinkronisasi & $3 \mathrm{kab} / \mathrm{kot}$ & $1 \mathrm{kab} / \mathrm{kot}$ & & & \\
\hline Tugas-tugas sudah dilakukan dengan simplikasi & $2 \mathrm{kab} / \mathrm{kot}$ & $1 \mathrm{kab} / \mathrm{kot}$ & $1 \mathrm{kab} / \mathrm{kot}$ & & \\
\hline Jumlah & $9 \mathrm{kab} / \mathrm{kot}$ & $5 \mathrm{kab} / \mathrm{kot}$ & $2 \mathrm{kab} / \mathrm{kot}$ & & \\
\hline
\end{tabular}

Sumber: data dari hasil gabungan daerah sampel 2014

Tabel 2. Koordinasi, Integrasi, Sinkronisasi dan Simplikasi Pemberdayaan Masyarakat

\begin{tabular}{|c|c|c|c|c|c|}
\hline Pemberdayaan Masyarakat & $\begin{array}{c}\text { Sangat } \\
\text { Baik }\end{array}$ & Baik & $\begin{array}{c}\text { Cukup } \\
\text { Baik }\end{array}$ & $\begin{array}{c}\text { Kurang } \\
\text { Baik }\end{array}$ & $\begin{array}{c}\text { Sangal } \\
\text { Kuran } \\
\text { Baik }\end{array}$ \\
\hline Melaksanakan koordinasi dengan lintas sektor terkait & $1 \mathrm{kab} / \mathrm{kot}$ & $3 \mathrm{kab} / \mathrm{kot}$ & & & \\
\hline Telah dilakukan dengan terIntegrasi & $2 \mathrm{kab} / \mathrm{kot}$ & $2 \mathrm{kab} / \mathrm{kot}$ & & & \\
\hline Tugas-tugas sudah dilakukan dengan sinkronisasi & $1 \mathrm{kab} / \mathrm{kot}$ & $3 \mathrm{kab} / \mathrm{kot}$ & & & \\
\hline Tugas-tugas sudah dilakukan dengan simplikasi & $2 \mathrm{kab} / \mathrm{kot}$ & $1 \mathrm{kab} / \mathrm{kot}$ & $1 \mathrm{kab} / \mathrm{kot}$ & & \\
\hline Jumlah & $6 \mathrm{kab} / \mathrm{kot}$ & $9 \mathrm{kab} / \mathrm{kot}$ & $1 \mathrm{kab} / \mathrm{kot}$ & & \\
\hline
\end{tabular}

Tabel 3. Koordinasi, Integrasi, Sinkronisasi dan Simplikasi Penyelenggaraan Ketentraman dan Ketertiban Umum

\begin{tabular}{|c|c|c|c|c|c|}
\hline Penyelenggaraan Ketentraman dan Ketertiban Umum & $\begin{array}{c}\text { Sangat } \\
\text { Baik }\end{array}$ & Baik & $\begin{array}{c}\text { Cukup } \\
\text { Baik }\end{array}$ & $\begin{array}{c}\text { Kurang } \\
\text { Baik }\end{array}$ & $\begin{array}{c}\text { Sangat } \\
\text { Kurang } \\
\text { Baik }\end{array}$ \\
\hline Melaksanakan koordinasi dengan lintas sektor terkait & $2 \mathrm{kab} / \mathrm{kot}$ & $2 \mathrm{kab} / \mathrm{kot}$ & & & \\
\hline Telah dilakukan dengan terIntegrasi & $2 \mathrm{kab} / \mathrm{kot}$ & $2 \mathrm{kab} / \mathrm{kot}$ & & & \\
\hline Tugas-tugas sudah dilakukan dengan sinkronisasi & $2 \mathrm{kab} / \mathrm{kot}$ & $2 \mathrm{kab} / \mathrm{kot}$ & & & \\
\hline Tugas-tugas sudah dilakukan dengan simplikasi & $2 \mathrm{kab} / \mathrm{kot}$ & $2 \mathrm{kab} / \mathrm{kot}$ & & & \\
\hline Jumlah & $8 \mathrm{kab} / \mathrm{kot}$ & $8 \mathrm{kab} / \mathrm{kot}$ & & & \\
\hline
\end{tabular}

Sumber: data dari hasil gabungan daerah sampel 2014

Tugas-tugas delegatif (PP 19 Tahun 2008) seperti perizinan, rekomendasi, koordinasi, pembinaan, pengawasan, fasilitasi, penetapan, penyelenggaraan pemerintahan telah dilaksanakan berdasarkan KISS (Koordinasi, Integrasi, Sinkronisasi dan Simplikasi) telah dilaksanakan dengan sangat baik terdapat $56,25 \%$ sedangkan yang menjawab baik berkisar antara $31,25 \%$ dan untuk yang menjawab cukup baik hanya 12,5\%. melihat dari hasil tersebut maka untuk KISS dalam melaksanakan tugas delegatif seperti perizinan, rekomendasi, koordinasi, pembinaan, pengawasan, fasilitasi, penetapan tidak mengalami hambatan.

Tugas-tugas atributif (PP 19 Tahun 2008) tugasumum pemerintahan seperti mengkoordinasikan kegiatan pemberdayaan masyarakat, mengkoordinasikan upaya penyelenggaraan ketentraman dan ketertiban umum, mengkoordinasikan penerapan dan penegakkan peraturan dan perundang-undangan, mengkoordinasikan pemeliharaan prasarana dan fasilitas pelayanan umum, mengkoordinasikan penyelenggaraan kegiatan pemerintahan di kecamatan, membina penyelenggaraan pemerintahan desa dan/kelurahan telah dilaksanakan dengan prinsif.

Tugas umum pemerintahan kecamatan dalam rangka pemberdayaan masyarakat berdasarkan KISS (Koordinasi, Integrasi, Sinkronisasi dan Simplikasi) masih dapat dikatakan baik terlihat dari hasilnya menunjukan bahwa peringkat pertama adalah baik sekitar 56,25\% dan dilanjuti dengan sangat baik berkisar 37,5\% dan terakhir dengan pernyataan cukup baik kisaran $6,25 \%$ hal ini menunjukan bahwa pada pemberdayaan masyarakat yang dilakukan berdasarkan KISS (Koordinasi, Integrasi, Sinkronisasi dan Simplikasi) dikatagorikan baik.

Penyelenggaraan ketenteraman dan ketertiban umum yang didasarkan KISS (Koordinasi, Integrasi, Sinkronisasi dan Simplikasi) cukup berimbang antara pernyataan sangat baik dan baik yaitu antara 50\% dengan pernyataan sangat baik dan pernyataan baik, sehingga dari data tesebut mengindikasikan bahwa penyelenggaraan ketenteraman dan ketertiban umum masih sangat baik dan baik. 
Tabel 4. Koordinasi, Integrasi, Sinkronisasi dan Simplikasi Penerapan dan Penegakkan Peraturan dan Perundang-Undangan

\begin{tabular}{|c|c|c|c|c|c|}
\hline $\begin{array}{c}\text { Penerapan dan Penegakkan Peraturan dan } \\
\text { Perundang-Undangan }\end{array}$ & $\begin{array}{l}\text { Sangat } \\
\text { Baik }\end{array}$ & Baik & $\begin{array}{l}\text { Cukup } \\
\text { Baik }\end{array}$ & $\begin{array}{l}\text { Kurang } \\
\text { Baik }\end{array}$ & $\begin{array}{c}\text { Sangat } \\
\text { Kurang } \\
\text { Baik }\end{array}$ \\
\hline Melaksanakan koordinasi dengan lintas sektor terkait & $2 \mathrm{kab} / \mathrm{kot}$ & $1 \mathrm{kab} / \mathrm{kot}$ & $1 \mathrm{kab} / \mathrm{kot}$ & & \\
\hline Telah dilakukan dengan terIntegrasi & $2 \mathrm{kab} / \mathrm{kot}$ & $1 \mathrm{kab} / \mathrm{kot}$ & $1 \mathrm{kab} / \mathrm{kot}$ & & \\
\hline Tugas-tugas sudah dilakukan dengan sinkronisasi & $2 \mathrm{kab} / \mathrm{kot}$ & $2 \mathrm{kab} / \mathrm{kot}$ & & & \\
\hline Tugas-tugas sudah dilakukan dengan simplikasi & $2 \mathrm{kab} / \mathrm{kot}$ & $1 \mathrm{kab} / \mathrm{kot}$ & $1 \mathrm{kab} / \mathrm{kot}$ & & \\
\hline jumlah & $8 \mathrm{kab} / \mathrm{kot}$ & $5 \mathrm{kab} / \mathrm{kot}$ & $3 \mathrm{kab} / \mathrm{kot}$ & & \\
\hline
\end{tabular}

Sumber: Data dari hasil gabungan daerah sampel 2014

Tabel 5: Koordinasi, Integrasi, Sinkronisasi dan Simplikasi Pemeliharaan Prasarana dan Fasilitas Pelayanan Umum

\begin{tabular}{|c|c|c|c|c|c|}
\hline $\begin{array}{l}\text { Pemeliharaan Prasarana dan Fasilitas Pelayanan } \\
\text { Umum }\end{array}$ & $\begin{array}{l}\text { Sangat } \\
\text { Baik }\end{array}$ & Baik & $\begin{array}{l}\text { Cukup } \\
\text { Baik }\end{array}$ & $\begin{array}{c}\text { Kurang } \\
\text { Baik }\end{array}$ & $\begin{array}{c}\text { Sangat } \\
\text { Kurang } \\
\text { Baik }\end{array}$ \\
\hline Melaksanakan koordinasi dengan lintas sektor terkait & $2 \mathrm{kab} / \mathrm{kot}$ & $2 \mathrm{kab} / \mathrm{kot}$ & & & \\
\hline Telah dilakukan dengan terIntegrasi & $2 \mathrm{kab} / \mathrm{kot}$ & $2 \mathrm{kab} / \mathrm{kot}$ & & & \\
\hline Tugas-tugas sudah dilakukan dengan sinkronisasi & $2 \mathrm{kab} / \mathrm{kot}$ & $2 \mathrm{kab} / \mathrm{kot}$ & & & \\
\hline Tugas-tugas sudah dilakukan dengan simplikasi & $2 \mathrm{kab} / \mathrm{kot}$ & $2 \mathrm{kab} / \mathrm{kot}$ & & & \\
\hline Jumlah & $8 \mathrm{Kab} / \mathrm{kot}$ & $8 \mathrm{Kab} / \mathrm{kot}$ & & & \\
\hline
\end{tabular}

Sumber: data dari hasil gabungan daerah sampel 2014

Tabel 6. Koordinasi, Integrasi, Sinkronisasi dan Simplikasi

Penyelenggaraan Kegiatan Pemerintahan di Kecamatan

\begin{tabular}{|c|c|c|c|c|c|}
\hline penyelenggaraan kegiatan pemerintahan di kecamatan & $\begin{array}{l}\text { Sangat } \\
\text { Baik }\end{array}$ & Baik & $\begin{array}{c}\text { Cukup } \\
\text { Baik }\end{array}$ & $\begin{array}{c}\text { Kurang } \\
\text { Baik }\end{array}$ & $\begin{array}{c}\text { Sangat } \\
\text { Kurang } \\
\text { Baik }\end{array}$ \\
\hline melaksanakan koordinasi dengan lintas sektor terkait & $2 \mathrm{kab} / \mathrm{kot}$ & $2 \mathrm{kab} / \mathrm{kot}$ & & & \\
\hline telah dilakukan dengan terIntegrasi & $2 \mathrm{kab} / \mathrm{kot}$ & $2 \mathrm{kab} / \mathrm{kot}$ & & & \\
\hline Tugas-tugas sudah dilakukan dengan sinkronisasi & $2 \mathrm{kab} / \mathrm{kot}$ & $2 \mathrm{kab} / \mathrm{kot}$ & & & \\
\hline Tugas-tugas sudah dilakukan dengan simplikasi & $2 \mathrm{kab} / \mathrm{kot}$ & $2 \mathrm{kab} / \mathrm{kot}$ & & & \\
\hline Jumlah & $8 \mathrm{kab} / \mathrm{kot}$ & $8 \mathrm{kab} / \mathrm{kot}$ & & & \\
\hline
\end{tabular}

Sumber: data dari hasil gabungan daerah sampel 2014

Tabel 7: Koordinasi, Integrasi, Sinkronisasi dan Simplikasi Membina

Penyelenggaraan Pemerintahan Desa dan Kelurahan Telah Dilaksanakan

\begin{tabular}{|c|c|c|c|c|c|}
\hline $\begin{array}{l}\text { Membina penyelenggaraan pemerintahan desa } \\
\text { dan/kelurahan telah dilaksanakan }\end{array}$ & $\begin{array}{l}\text { Sangat } \\
\text { baik }\end{array}$ & Baik & $\begin{array}{l}\text { Cukup } \\
\text { baik }\end{array}$ & $\begin{array}{l}\text { Kurang } \\
\text { baik }\end{array}$ & $\begin{array}{c}\text { Sangat } \\
\text { kurang } \\
\text { baik }\end{array}$ \\
\hline Melaksanakan koordinasi dengan lintas sektor terkait & $2 \mathrm{kab} / \mathrm{kot}$ & $2 \mathrm{kab} / \mathrm{kot}$ & & & \\
\hline Telah dilakukan dengan terintegrasi & $2 \mathrm{kab} / \mathrm{kot}$ & $2 \mathrm{kab} / \mathrm{kot}$ & & & \\
\hline Tugas-tugas sudah dilakukan dengan sinkronisasi & $2 \mathrm{kab} / \mathrm{kot}$ & $2 \mathrm{kab} / \mathrm{kot}$ & & & \\
\hline Tugas-tugas sudah dilakukan dengan simplikasi & $2 \mathrm{kab} / \mathrm{kot}$ & $2 \mathrm{kab} / \mathrm{kot}$ & & & \\
\hline jumlah & $8 \mathrm{kab} / \mathrm{kot}$ & $8 \mathrm{kab} / \mathrm{kot}$ & & & \\
\hline
\end{tabular}

Sumber: data dari hasil gabungan daerah sampel 2014

Penerapan dan penegakan peraturan dan perundang-undangan yang dilakukan kecamatan berdasarkan KISS (Koordinasi, Integrasi, Sinkronisasi dan Simplikasi) memperoleh data bahwa pelaksanaan tersebut sangat baik terbukti dengan hasilnya 50\% sedangkan untuk pernyataan baik $31,25 \%$ dan pernyataan cukup baik memperoleh $19,75 \%$ dengan demikian pernyataan penerapan dan penegakan peraturan dan perundangan-undangan dapat dikatagorikan pelaksanaannya sangat baik.

Pemeliharaan prasarana dan fasilitas pelayanan umum yang didasarkan KISS (Koordinasi, Integrasi, Sinkronisasi dan Simplikasi) cukup berimbang antara 
pernyataan sangat baik dan baik yaitu antara $50 \%$ dengan pernyataan sangat baik dan pernyataan baik, sehingga dari data tesebut mengindikasikan bahwa pemeliharaan prasarana dan fasilitas pelayanan umum masih sangat baik dan baik.

Penyelenggaraan kegiatan pemerintahan di kecamatan yang didasarkan KISS (Koordinasi, Integrasi, Sinkronisasi dan Simplikasi) cukup berimbang antara pernyataan sangat baik dan baik yaitu antara $50 \%$ dengan pernyataan sangat baik dan pernyataan baik, sehingga dari data tesebut mengindikasikan bahwa . penyelenggaraan kegiatan pemerintahan di kecamatan masih sangat baik dan baik.

Membina penyelenggaraan pemerintahan desa dan/kelurahan telah dilaksanakan yang didasarkan kiss (koordinasi, integrasi, sinkronisasi dan simplikasi) cukup berimbang antara pernyataan sangat baik dan baik yaitu antara $50 \%$ dengan pernyataan sangat baik dan pernyataan baik, sehingga dari data tesebut mengindikasikan bahwa membina penyelenggaraan pemerintahan desa dan/kelurahan telah dilaksanakan masih sangat baik dan baik. apabila dikaitkan dengan undang-undang 6 tahun 2014 tentang pemerintahan Desa maka aparatur kecamatan tidak perlu lagi mengeluarkan energi yang ekstra karena walaupun dalam Undang-Undang tersebut keterlibatan hanya sebatas pelaporan dari desa ke Kabupaten/walikota namun dengan mekanisme yang tak tertulis dari undang-Undang tersebut keberdaan kecamatan masih diperlukan walaupun hanya sebatas pelaporan dan sekaligus sebagai pembina keluarahan dan desa.

\section{SIMPULAN}

Dalam penelitian peran dan fungsi kecamatan dalam penyelenggaraan pemerintahan daerah di Provinsi Jawa Tengah pada Kota Semarang pada kecamatan Gunungpati dan kecamatan Pedurungan serta Kabupaten Semarang kecamatan Ungaran Timur dan kecamatan Bergas, kewenangan yang dilimpahkan dari walikota maupun bupati khususnya di Kota Semarang sudah ada yaitu melalui Perwali Nomor 19 Tahun 2012 tentang perubahan atas peraturan walikota Semarang Nomor 34 Tahun 2009 Tentang Pendelegasian sebagian urusan pemerintahan yang menjadi kewenangan walikota kepada camat kota Semarang dan untun di Kabupaten Semarang melalui peraturan bupati Semarang Nomor 117 Tahun 2012 tentang pelimpahan sebagian kewenangan bupati Semarang kepada camat di Kabupaten Semarang dan Nomor 18 Tahun 2007 Tentang Pelimpahan sebagian kewenangan bupati Semarang kepada lurah di Kabupaten Semarang namun dalam pelaksanaannya belum sepenuhnya di terapkan aturan tersebut untuk di Kabupaten dan walikota hanya perijinan mendirikan bangunan yang kurang dari 200 meter baru diserahkan kecamatan.

Struktur organisasi kecamatan yang berada di wilayah Kabupaten Semarang dengan melakukan miskin struktur kaya fungsi untuk beberapa kecamatan mungkin dapat berfungsi dengan baik namun untuk kecamatan yang berbatasan dengan kota Semarang menjadi sangat menyulitkan karena harus dituntut dengan kinerja yang optimal. Untuk Kota Semarang belum menggunakan struktur organisasi yang berada di PP 41 Tahun 2007 tentang organisasi perangkat daerah sehingga masih juga ada yang merasa struktur tersebut kurang okomodatif.

Sumber Daya Manusia moratorium di kecamatan yang berada pada wilayah Kota Semarang dan Kabupaten Semarang sangat kesulitan sehingga seorang Kepala Seksi yang berada di Kecamatan dan Kelurahan hampir sebagian besar tidak memiliki fungsional umum yang membantunya semua dikerjakan sendiri dari mulai foto copy hingga membuat konsep surat rekomendasi.

Manajemen Kecamatan dalam melaksanakan tugas atributif dan delegatif mendapat peanggarannya dari APBD dan APBN serta dari pihak ketiga serta mendapat dukungan dari Kepala Daerah dan Masyarakat, namun dalam menjalankan tugas pelayanan umum dan sosial kemasyarakatan masih diperlukan dengan dana dari uang pribadi seperti menghadiri hajat besar sosial kemasyarakatan.

Terkait dengan Koordinasi/Integrasi/ Sinkronisasi/Simplikasi (KISS) terhadap pelaksanaan tugas atributif dan delegatif dalam rangka menjalin kesatuan dan persatuan bangsa (Negara Kesatuan Republik Indonesia) sudah berjalan baik selama fungsi kecamatan sebagai kepala wilayah.

\section{Saran}

Mengamati dan mempertimbangkan hasil dari kesimpulan tersebut untuk itu perlu juga disarankan antara lain, kewenangan yang telah dilimpahkan oleh bupati walikota kepada kecamatan sudah ada secara normatif namun dalam pelaksanaannya masih setengah setengah intuk itu kewenangan yang telah diberikan harus sepenuhnya diberikan dan hendaknya diikuti dengan anggaran yang cukup dan memadai. struktur kecamatan yang terdapat di kabuapten Semarang dan Kota Semarang masih mengacu kepada Peraturan Pemerintah 41 Tahun 2007 tentang organisasi perangkat daerah untuk itu perlu menyesuaikan kembali dengan sturutur organisasi yang terdapat di Peraturan Pemerintah 19 Nomor 2008 tentang Kecamatan, di aturan tersebut memutuskan adanya unsur kepala subbagian sebanyak 3 (tiga) di bawah sekretaris kecamatan.Kementerian Pendayagunaan Aparatur Negara dan Reformasi Birokrasi hendaknya membuka kran kembali penerimaan aparatur guna mengisi kekosongan di kecamatan dan kelurahan, penganggaran untuk kecamatan seyogyanya perlu diantisipasi dengan dana taktis atau dana non badget untuk mengakomodir pengeluaran camat dalam mengunjungi atau menyambangi kegiatan sosial kemasyarakatan. 


\section{DAFTAR PUSTAKA}

Anwar, Dewi Fortuna, Helena Bouvier, Glenn Smith, and Roger Tol. 2005. Konflik Kekerasan Internal: Tinjauan Sejarah, Ekonomi-Politik, dan Kebijakan di Asia Pasifik. Jakarta: Yayasan Obor Indonesia

Barkey, Karen, and Sunita Parikh. 1991. "Comparative Perspectives on the State", dalam, Annual Review Sociology, Vol.17

Bayu Surianingrat, 1981. Wewenang, Tugas dan Tanggung Jawab camat, Cetakan I, Penerbit Patco, Jakarta-Surabaya

Brian Smith, 1985. Decentralization, London, UK: George Allen and Unwin

Bhakti, Ikrar Nusa dan Irine H.Gayatri (editor), 2002. Unitary State versus Federal State. Jakarta: PPW LIPI dan NDI-Mizan-Hanns Seidel Foundation-GTZ-TAMF

Bhakti, Ikrar Nusa (Ed.) 2008. Beranda Perdamaian, Aceh Tiga Tahun Pasca MoU Helsinki. Yogyakarta: Kerjasama P2P LIPI-Pustaka Pelajar

Budiardjo, Miriam.1978. Dasar-Dasar Ilmu Politik. Jakarta: Gramedia

Eko Prasojo (dkk) 2006. Desentralisasi dan Pemerintahan Daerah: Antara Model Demokrasi Lokal dan Efisiensi Struktural. Jakarta: FISIP UI.

Elizabeth, Adriana, Muridan Widjojo, Cahyo Pamungkas (dkk)2005. Agenda dan Potensi Damai di Papua. Jakarta: LIPI-The Friedrich Ebert Foundation-the West Papua

Gie, The Liang. 1967. Sejarah Pertumbuhan Pemerintahan Daerah di Indonesia, jilid I. Jakarta: Gunung Agung.

Gie, The Liang. 1968. Sejarah Pertumbuhan Pemerintahan Daerah di Indonesia. Jakarta: Gunung Agung

Gonggong, Anhar. 2000. "Pilihan Jalan Simpang antara Negara Kesatuan atau Federal: Penglihatan Sejarah dan Keamanan".

Harry Friedman, 1983. Decentralized Development in Asis, dalam Shabbir Cheema and Dennis Rondinelli, Decentralization and Development, Beverly Hills, CA: Sage Publications

Hidayat, Syarif. 2003. "Desentralisasi dalam Perpektif State-Society Relation: Rekonsruksi

Konsep dan Pendekatan Kebijakan”. Dalam Tim LIPI. Desentralisasi dan Otonomi

Daerah, Naskah Akademik dan RUU Usulan LIPI. Jakarta: P2P LIPI-PGRI;

Kahin, Audrey.2005. Dari Pemberontakan ke Integrasi Sumatra Barat dan Politik Indonesia 1926-1998. Jakarta: Yayasan Obor Indonesia;

Legge, J.D. 1963. Central Authority and Regional Autonomy in Indonesia, A Study in Local Administration 1950-1960. Ithaca New York: Cornell University Press

Leirissa, R.Z. 1997. PRRI PERMESTA. Strategi Membangun Indonesia Tanpa Komunis. Jakarta:

Grafiti Liddle, R. William (editor). 2001. Crafting Indonesian Democracy. Jakarta: PPW-LIPI kerja sama dengan the Ford Foundation-Mizan

Maddick, 1963. Democracy, Desentralization and Development, Bombay, India: Asia
Publishing House

Maryanov, Gerald S. 1959. The Establishment of Regional Government in the Republic of

Indonesia. Disertasi. The Departement of Government Indiana University

M.Solly Lubis, 1983. Perkembangan Garis Politik dan Perundang-Undangan Pemerintahan Daerah. Bandung: Penerbit Alumni

Muhadam Labolo, 2000. "Dilema Penyelenggaraan Dekonsentrasi”, dalam Jurnal Pamong Praja, Jakarta: Edisi 1-2004

Philip Mawhood, 1983. Local Government in the Third World, (Chicester, UK: John Wisley and Sons

Sadu Wasistiono, Ismail Nurdin dan M.Fahrurozi, 2009. Perkembangan Organisasi Kecamatan Dari Masa Ke Masa, Cetakan I, Penerbit Fokus Media, Bandung

Haris, Syamsuddin. "Pendahuluan". Dalam Tim LIPI. Desentralisasi dan Otonomi Daerah, Naskah Akademik dan RUU Usulan LIPI. Turner, Hulme.Op cit., hlm.154.

Jurnal dan terbitan sejenisnya:

Jurnal Analisis CSIS Tahun XXIX/2000 No.1;

Sekretariat Negara RI. 1992. Risalah Sidang-Sidang BPUPKI. Jakarta: Setneg RI.

Makalah Universitas Diponegoro. Pemilihan Kepala Desa Sebagai Perwujudan Nilai-Nilai Demokrasi. Seminar tanggal 9 Desember 1989. Semarang

Watch Indonesia! 2003. Autonomy for Рapua Opportunity or Illusion? Kumpulan makalah Jerman. dipresentasikan pada 4 dan 5 Juni di Berlin,

Dokumentasi perundang-undangan:

Ensiklopedi Administrasi, tahun 1977

Undang-Undang Dasar Tahun 1945 Amandemen IV;

Undang-Undang Nomor 1 Tahun 1957;

Undang-Undang Nomor 18 Tahun 1955;

Undang-Undang Nomor 5 Tahun 1974;

Undang-Undang Nomor 22 Tahun 1999 tentang Pemerintahan Daerah;

Undang-Undang Nomor 25 Tahun 2004;

Undang-Undang Nomor 32 Tahun 2004 tentang Pemerintahan Daerah;

Undang-Undang Nomor 33 Tahun 2004 tentang Perimbangan Keuangan antara Pemerintah Pusat dan Daerah;

Undang-Undang Nomor 6 Tahun 2014 tentang Desa; Peraturan Pemerintah No. 19 Tahun 2008;

Peraturan Menteri Dalam Negeri Nomor 13 Tahun 2006. 


\section{Biodata Penulis}

\begin{abstract}
Abdul Hamid
Abdul Hamid, lahir di Muara Aman, Rejang Lebong, Provinsi Bengkulu pada 12 Agustus 1960. Memeroleh gelar doktor dengan menyelesaikan pendidikan S3 Ilmu Pertanian di Universitas Brawijaya pada tahun 2002, pendidikan S2 Ilmu Kehutanan di Universitas Gajah Mada pada tahun 1994, dan pendidikan S1 Budidaya Pertanian di Universitas Bengkulu pada 1986. Saat ini bekerja sebagai Fungsional Peneliti pada Badan Penelitian dan Pengembangan Daerah Provinsi Jawa Timur dengan jabatan Peneliti Madya Golongan IV/c Bidang Kebijakan Publik.
\end{abstract}

\section{Moh. Ilham A. Hamudy}

Lahir di Makassar, 21 November 1980. Saat ini bekerja pada Badan Penelitian dan Pengembangan Kementerian Dalam Negeri sebagai Pejabat Fungsional Peneliti. Menyelesaikan pendidikan S1 di Universitas Padjajaran Bandung Jurusan Ilmu Pemerintahan dan menyelesaikan pendidikan Pascasarjana di Universitas Nasional Malaysia jurusan Ilmu Politik.

\section{Muhammad Soleh Pulungan}

Lahir pada 7 Oktober 1966. Saat ini bekerja pada Balitbangda Kutai Kartanegara, Provinsi Kalimantan Timur sebagai Peneliti Muda Bidang Kebijakan Pendidikan. Selain itu juga menjabat sebagai Koordinator Fungsional Peneliti Balitbangda Kukar-Kaltim. Menyelesaikan pendidikan program sarjana Pendidikan Universitas Negeri Yogyakarta pada 1994, kemudian menyelesaikan program Magister Hukum di Universitas Putra Bangsa Surabaya pada 2004.

\section{Asrori}

Lahir di Kudus, Jawa Tengah pada 7 Juni 1963. Saat iini bekerja sebagai Fungsional Peneliti dengan jabatan Peneliti Utama golongan IV/d pada Badan Penelitian dan Pengembangan Kementerian Dalam Negeri. Menyelesaikan pendidikan di APMD di Yogyakarta pada 1987 dan pendidikan di STPMD Yogyakarta pada 1990.

\section{Bambang Sunaryo}

Bekerja sebagai tenaga pengajar aktif di Jurusan Manajemen dan Kebijakan Publik Fisipol Universitas Gajah Mada. Menyelesaikan Master graduate school Asian Institute of Technology Thailand pada 1986, pendidikan magister Administrasi Negara Fisipol UGM pada 1985 dan pendidikan sarjana Administrasi Negara Fisipol UGM pada 1981. Memiliki ketertarikan dalam penelitian mengenai desentralisasi, birokrasi dan perencanaan pembangunan.

\section{Celly Cicellia}

Lahir di Ngawi, Jawa Timur pada 14 Agustus 1988. Menyelesaikan pendidikan S2 Manajemen dan Kebijakan
Publik Fisipol UGM pada 2013 dan pendidikan Sarjana Administrasi Negara Fisipol UGM pada 2011. Bekerja sebagai Asisten Dosen Mata Kuliah Metode Penelitian Sosial, Kebijakan Publik, dan Perencanaan Pembangunan di Jurusan Manajemen dan Kebijakan Publik Fisipol UGM. Juga sebagai peneliti bidang Kebijakan Publik dan Sosial di Housing Research Center Yogyakarta.

\section{Gusti Syahrany Noor}

Lahir di Kotabaru, Kalimantan Selatan pada 27 Mei 1956. Pada saat ini bekerja sebagai Fungsional Peneliti pada Badan Penelitian dan Pengembangan Daerah Provinsi Kalimantan Selatan dengan Bidang Kepakaran Kayu. Menyelesaikan pendidikan sarjana jurusan Hasil Hutan Fakultas Kehutanan pada 1982.

\section{Gunawan}

Lahir di Jakarta pada 11 November 1964. Menyelesaikan pendidikan Sarjana Administrasi Negara di Sekolah Tinggi Ilmu Administrasi Negara pada 1996. Pada saat ini bekerja sebagai Peneliti Muda (III/c) Bidang Kepakaran Kebijakan Publik dan Administrasi pada Pusat Pemerintahan Umum dan Kependudukan Badan Penelitian dan Pengembangan Kementerian Dalam Negeri. 



\section{Pedoman Penulisan}

1. Artikel ditulis dengan bahasa Indonesia atau bahasa Inggris dalam bidang kajian pemerintahan dalam negeri/pemerintahan daerah.

2. Substansi artikel diharapkan sejalan dengan Panduan Akreditasi Berkala Ilmiah, yang diterbitkan Badan Penelitian dan Pengembangan Kementerian Dalam Negeri. http://www.bpp.depdagri.go.id/....

3. Artikel ditulis dengan kaidah tata bahasa Inggris ataupun bahasa Indonesia yang baku, baik, dan benar.

4. Sistematika Penulisan

Sistematika penjenjangan atau peringkat judul artikel dan bagian-bagiannya dilakukan dengan cara berikut:

(1) Judul ditulis dengan huruf besar semua, di bagian tengah atas pada halaman pertama;

(2) Sub Bab Peringkat 1 ditulis dengan huruf pertama besar semua rata tepi kiri;

(3) Sub Bab Peringkat 2 ditulis dengan huruf besar-kecil rata tepi kiri.

- Sistematika artikel hasil penelitian adalah: judul; nama penulis (tanpa gelar akademik); nama dan alamat institusi, alamat e-mail penulis, abstrak (maksimum 150 kata dalam bahasa Inggris dan 250 kata dalam bahasa Indonesia) yang berisi tujuan, metode, dan hasil penelitian; kata kunci (4-5 kata kunci); pendahuluan (tanpa ada subjudul) yang berisi latar belakang, sedikit tinjauan pustaka, dan tujuan penelitian; metode; hasil penelitian dan pembahasan; simpulan; daftar rujukan (hanya memuat sumber-sumber yang dirujuk).

JUDUL (ringkas dan lugas; maksimal 14 kata, hindari kata “analisis”, “studi”, “pengaruh”)

Penulis $1^{1}$ dan Penulis $2^{2}$

${ }^{1}$ Nama instansi/lembaga Penulis 1

Alamat lengkap instansi penulis, nomor telepon instansi penulis

${ }^{2}$ Nama instansi/lembaga Penulis 2

Alamat lengkap instansi penulis, nomor telepon instansi penulis

(jika nama instansi penulis 1 dan 2 sama, cukup ditulis satu saja)

E-mail penulis 1 dan 2:

Abstract: Abstract in english (max. 150 words)

Keywords: 4 - 5 words/ phrase (separated with ;)

Abstrak: Abstrak dalam bahasa Indonesia (maks. 250 kata)

Kata kunci: 4 - 5 kata/ frasa (dipisahkan dengan ;)

PENDAHULUAN

(berisi latar belakang, sekilas tinjauan pustaka, dan tujuan penelitian, yang dimasukkan dalam paragraf-paragraf bukan dalam bentuk subbab)

METODE PENELITIAN

Subbab

...

HASIL DAN PEMBAHASAN

(Hasil adalah gambaran lokus. Pembahasan adalah analisa dan interpretasi penulis)

Subbab

...

SIMPULAN

(Simpulan adalah hasil dari pembahasan yang menjawab permasalahan penelitian) 
- Sistematika artikel hasil pemikiran/reviu/telaahan adalah: judul; nama penulis (tanpa gelar akademik); nama dan alamat institusi, alamat e-mail penulis, abstrak (maksimum 150 kata dalam bahasa Inggris dan 25 kata dalam bahasa Indonesia); kata-kata kunci (4-5 kata kunci); pendahuluan (tanpa ada subjudul) yang berisi latar belakang dan tujuan atau ruang lingkup tulisan; bahasan utama (dapat dibagi ke dalam beberapa sub-judul); simpulan; daftar rujukan (hanya memuat sumber-sumber yang dirujuk).

\section{JUDUL}

\section{Penulis}

Nama instansi/lembaga Penulis

Alamat lengkap instansi penulis, nomor telepon instansi penulis E-mail penulis

Abstract: Abstract in English (max. 150 words)

Keywords: $4-5$ words/ phrase

Abstrak: Abstrak dalam bahasa Indonesia (maks. 250 kata)

Kata kunci: 4 - 5 kata/ frasa

\section{PENDAHULUAN \\ PEMBAHASAN \\ PENUTUP \\ DAFTAR PUSTAKA}

5. Artikel diketik pada kertas ukuran A4 berkualitas baik. Dibuat sesingkat mungkin sesuai dengan subyek dan metode penelitian (bila naskah tersebut ringkasan penelitian), biasanya 20-25 halaman dengan spasi satu, untuk kutipan paragraf langsung diindent (tidak termasuk daftar pustaka).

6. Abstrak, ditulis satu paragraf sebelum isi naskah. Abstrak dalam dua bahasa yaitu bahasa Indonesia dan bahasa Inggris. Abstrak tidak memuat uraian matematis, dan mencakup esensi utuh penelitian, metode dan pentingnya temuan dan saran atau kontribusi penelitian.

7. a. Penulisan numbering kalimat pendek diintegrasikan dalam paragraf, contohnya:

Tujuan dilakukannya penelitian ini adalah: (1) Untuk mengetahui apakah CSR berpengaruh positif terhadap nilai perusahaan; (2) Untuk mengetahui apakah persentase kepemilikan manajemen berperan sebagai variabel moderating dalam hubungan antara CSR dengan nilai perusahaan; dan (3) Untuk mengetahui apakah tipe industri berperan sebagai variabel moderating dalam hubungan antara CSR dengan nilai perusahaan?

b. Penulisan bullet juga diintegrasikan dalam paragraf dengan menggunakan tanda titik koma pada antarkata/kalimat tanpa bullet.

8. Tabel dan gambar, untuk tabel dan gambar (grafik) sebagai lampiran dicantumkan pada halaman sesudah teks. Sedangkan tabel atau gambar baik di dalam naskah maupun bukan harus diberi nomor urut.

a. Tabel atau gambar harus disertai judul. Judul tabel diletakkan di atas tabel sedangkan judul gambar diletakkan di bawah gambar.

b. Sumber acuan tabel atau gambar dicantumkan di bawah tabel atau gambar.

c. Garis tabel yang dimunculkan hanya pada bagian header dan garis bagian paling bawah tabel sedangkan untuk garis-garis vertikal pemisah kolom tidak dimunculkan.

d. Tabel atau gambar bisa diedit dan dalam tampilan berwarna yang representatif.

e. Ukuran resolusi gambar minimal $300 \mathrm{dpi}$.

Contoh Penyajian Tabel:

Tabel 1. Bentuk-Bentuk Mobilitas Penduduk

\begin{tabular}{cccc}
\hline No. & Bentuk Mobilitas & Batas Wilayah & \multicolumn{1}{c}{ Batas Waktu } \\
\hline 1. & Ulang-alik (commuting) & Dukuh & 6 jam atau lebih, kembali pada hari yang sama \\
2. & Mondok di daerah tujuan & Dukuh & Lebih dari satu hari tetapi kurang dari 6 bulan \\
3. & Menetap di daerah tujuan & Dukuh & 6 bulan atau lebih menetap di daerah tujuan \\
\hline \multicolumn{2}{l}{ Sumber: Ida Bagoes, 2000}
\end{tabular}




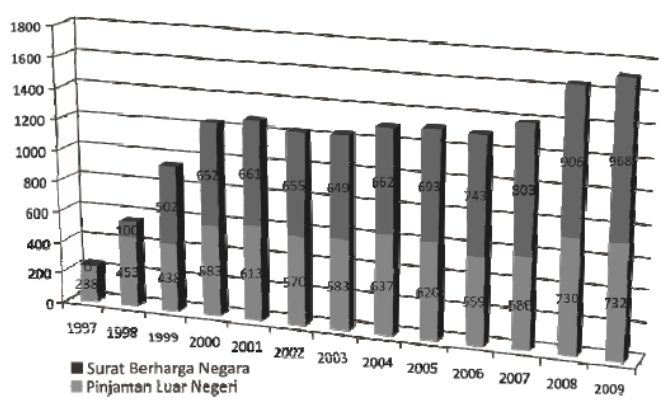

Sumber: Bank Indonesia, 2009

Gambar 1. Utang Indonesia (dalam triliun Rupiah)

9. Cara penulisan rumus. Persamaan-persamaan yang digunakan disusun pada baris terpisah dan diberi nomor secara berurutan dalam parentheses (justify) dan diletakkan pada margin kanan sejajar dengan baris tersebut. Contoh: $\mathrm{wt}=\mathrm{f}(\mathrm{yt}, \mathrm{kt}, \mathrm{wt}-1)$

10. Keterangan rumus ditulis dalam satu paragraf tanpa menggunakan simbol sama dengan (=), masingmasing keterangan notasi rumus dipisahkan dengan koma. Contoh:

dimana w adalah upah nominal, yt adalah produktivitas pekerja, kt adalah intensitas modal, wt-1 adalah tingkat upah periode sebelumnya

11. Perujukan sumber acuan di dalam teks (body text) dengan menggunakan nama akhir dan tahun. Kemudian bila merujuk pada halaman tertentu, penyebutan halaman setelah penyebutan tahun dengan dipisah titik dua. Untuk karya terjemahan dilakukan dengan cara menyebutkan nama pengarang aslinya.

Contoh:

- Buiter (2007:459) berpendapat bahwa...

- Fatimah dan Daryono (1997) menunjukkan adanya...

- Didit $d k k$ (2007) berkesimpulan bahwa...

- Untuk meningkatkan perekonomian daerah... (Yuni, Triyono, dan Agung Riyardi, 2009)

- Maya (2009) berpendapat bahwa...

12. Setiap kutipan harus diikuti sumbernya (lihat poin no.11) dan dicantumkan juga dalam daftar pustaka. Contoh:

Di dalam paragraf isi (Body Text) ada kutipan:

Buiter (2007:459) berpendapat bahwa...

Maka sumber kutipan tersebut wajib dicantumkan/disebutkan di dalam daftar pustaka:

Buiter, W.H. 2007. The Fiscal Theory of the Price Level: A Critique, Economic Journal. 112(127):459

13. Sedapat mungkin pustaka-pustaka yang dijadikan rujukan adalah pustaka yang diterbitkan 10 tahun terakhir dan diutamakan lebih banyak dari Jurnal Ilmiah (50 persen). Penulis disarankan untuk merujuk artikel-artikel pada Jurnal Bina Praja dari edisi sebelumnya.

14. Unsur yang ditulis dalam daftar pustaka secara berturut-turut meliputi: (1) nama akhir pengarang, nama awal, nama tengah, tanpa gelar akademik; (2) tahun penerbitan; (3) judul termasuk subjudul; (4) tempat penerbitan; dan (5) nama penerbit.

Contoh cara penulisan:

a. Format rujukan dari buku: Nama pengarang. (tahun). Judul Buku. Edisi. Kota penerbit: Nama penerbit.

Jika penulis sebagai editor tunggal, ditulis (Ed.) di belakang namanya. Ditulis (Eds.) jika editornya lebih dari satu orang. Kemudian bila pengarang lebih dari tiga orang, dituliskan nama pengarang pertama dan yang lain disingkat ' $d k k$ ' (pengarang domestik) atau 'et.al' (pengarang asing)

Enders, W. 2004. Applied Econometric Time Series. Second edition. New York: John Wiley \& Son.

Purnomo, Didit (Ed.). 2005. The Role of Macroeconomic Factors in Growth. Surakarta: Penerbit Muhammadiyah University Press

b. Format rujukan dari artikel dalam buku ditulis: Nama editor (Ed.). (tahun). Judul tulisan/karangan. Judul buku. hlm atau pp. kota penerbit: nama penerbit.

Daryono (Ed.). 2005. Concept of Fiscal Decentralization and Worldwide Overview (hlm. 12-25). Surakarta: Penerbit Muhammadiyah University Press. 
c. Format rujukan dari artikel dalam jurnal/majalah/koran: Nama pengarang (tahun). judul tulisan/karangan. Nama jurnal/majalah/koran. volume (nomor): halaman. Jika rujukan koran tanpa penulis, nama koran ditulis diawal

Rodden, J. 2002. The Dilemma of Fiscal Federalism: Grants and Fiscal Performance around the World. American Economic Journal. 46 (3): 670. Nashville: American Economic Association.

Triyono. 2008. Perimbangan Keuangan Pusat dan Daerah Sebagai Pelaksanaan Desentralisasi Fiskal Efek. Warta Ekonomi. Vol. 4. Agustus: 46-48

Haryanto, S. 2007, 13 November. Desentralisasi Fiskal dan Pembangunan Ekonomi. Harian Jakarta. hlm.4.

Harian Jogjakarta. 2007, 1 April. Hubungan Keuangan Pusat-Daerah di Indonesia. hlm.4.

d. Format rujukan dari internet, tanggal akses dicantumkan.

Setyowati, E. Keuangan Publik dan Sistem Harga. http://www.ekonomipublik.com/akt/pdf/ akt452.pdf. Diakses tanggal 27 Mei 2009.

15. Referensi Online yang dianjurkan dalam penggunaan bahasa Indonesia:

a. Glosarium kata baku dari Pusat Bahasa Departemen Pendidikan Nasional Republik Indonesia: http://pusatbahasa.diknas.go.id/glosarium/

b. Kamus Besar Bahasa Indonesia dari Pusat Bahasa Departemen Pendidikan Nasional Republik Indonesia: http://pusatbahasa.depdiknas.go.id/kbbi/

c. Pedoman Umum Ejaan Bahasa Indonesia yang Disempurnakan (EYD): http://pusatbahasa.depdiknas.go.id/lamanv4/sites/default/files/EJD-KKP-PBNBID.PENGEMBANGAN.pdf

\title{
Pengiriman Artikel
}

1. Artikel dikirimkan sebanyak 2 eksemplar hardcopy, dan softcopy berupa file. File bisa dikirim melalui email jurnalbinapraja@yahoo.com atau dalam media cd.

2. Artikel yang dikirim wajib dilampiri biodata ringkas pendidikan termasuk catatan riwayat karya-karya ilmiah sebelumnya yang pernah dipublikasikan, insitusi dan alamatnya, nomor telpon kontak atau e-mail penulis.

3. Penulis yang menyerahkan artikelnya harus menjamin bahwa naskah yang diajukan tidak melanggar hak cipta, belum dipublikasikan atau telah diterima untuk dipublikasi oleh jurnal lainnya.

4. Kepastian naskah dimuat atau tidak, akan diberitahukan secara tertulis. Artikel yang tidak dimuat tidak akan dikembalikan.

\author{
Alamat Jurnal Bina Praja: \\ Badan Penelitian dan Pengembangan \\ Kementerian Dalam Negeri \\ Jalan Kramat Raya No. 132, Senen - Jakarta 10420 \\ Telepon/Fax: +62 213101953 / +62 213924451 \\ e-mail: jurnalbinapraja@yahoo.com
}

